\title{
An overview of coal rank influence on ignition and combustion phenomena at the particle level.
}

\author{
Reza Khatami and Yiannis A. Levendis* \\ Mechanical and Industrial Engineering \\ Northeastern University, Boston, MA 02115, USA \\ Tel \# (617) 373-3806 Fax \# (617) 373-2921 \\ *Corresponding Author, e-mail: y.levendis@neu.edu
}

\begin{abstract}
Individual particles of pulverized coals exhibit strikingly different combustion phenomena depending on their rank (anthracite, semi-anthracite, bituminous, sub-bituminous and lignite). Herein a concise review is presented on pertinent findings in the literature to contrast ignition and combustion behavior of such fuels at the particle-level. Emphasis is given to recent investigations performed in the laboratory of the authors, where combustion of a variety of coal particles of the same size-cut took place in the same apparatus under identical operating conditions. Such behaviors were then compared to those reported in the literature to verify their replication under often different, but yet relevant, conditions. The objective has been to relate the effect of coal rank to a number of key qualitative and quantitative parameters, such as modes of ignition and combustion, ignition temperatures, ignition delay times, combustion temperatures and burnout times (both those encountered in the volatile and the char combustion phases), volatile flame sizes as well as extents of particle fragmentation. Besides reviewing combustion behaviors in air, analogous behaviors under simulated dry oxy-combustion conditions were also highlighted. Then the coal rank dependence of the required oxygen mole fraction in dry $\mathrm{O}_{2} / \mathrm{CO}_{2}$ blends to match the intensity of air-fired combustion was examined.
\end{abstract}

Key words: Coal rank, coal particle ignition, coal particle combustion, oxy-coal combustion, biomass particle, temperature, burnout time, fragmentation.

\section{Introduction}

Coal has been traditionally used to supply a great deal of the world's electric power generation needs. In recent years, approximately $40 \%$ of the world's electricity is generated by burning coal [1], and it has been projected that the global utilization of coal will continue in the foreseeable future as it is "abundant and cheap" [1-3]. This is particularly true for South Africa, 
China, Poland, Australia, India and other countries where more than two thirds of their electricity is currently generated from burning coal [4]. While global utilization of coal is increasing, in some countries usage for power generation has been declining in recent years. This is due to the competition from plentiful, low-priced and much cleaner-burning natural gas, as a result of rapid development of extraction techniques involving hydraulic fracturing ("fracking") in shale formations. However, a relevant opinion article [5] pointed out that the supply of affordable natural gas in the US has a finite lifetime and, as the price of natural gas increases in the future, the use of coal will rebound again, particularly if "clean-coal technologies", such as capture and sequestration of global $\mathrm{CO}_{2}$ emissions (CCS), are proven and implemented [5].

To promote clean coal utilization, it is also important to improve the performance and efficiency of boilers and associated devices. To this end, a thorough understanding is needed of the combustion behaviors of different feedstock fuels under various operating conditions, pertinent to both conventional and future combustion technologies. It is well-established that particle combustion characteristics influence the design of the dimensions of pulverized fuel boilers [6].

Assessing the combustion behavior of solid fuels has been the subject of a very large number of studies in more than half a century, including Refs. [7-100] herein, with emphasis on the quantification of particle temperatures, burnout durations, as well as time delays for the particles to ignite. Such parameters affect the design of furnaces, as combustion durations affect the residence times of the combustibles therein, which then influence the selection of furnace flow-rates, which in turn affect the dimensions of furnaces. Elevated temperature profiles affect the radiative properties of the particles and gases and the convective properties of their combustion products, which in turn affect the type, dimensions and placement of the furnace/boiler heat transfer surfaces. Understandably, combustion characteristics are not the only factors that affect furnace design, as there are other influential factors as well, such as fuel particle sizing, feeding rates, fuel to air ratios, etc. Furthermore, particle combustion characteristics influence the slagging and fouling propensity therein as well as the emissions of gaseous- and solid-phase pollutants therefrom. For instance, based on numerical simulation models of boiler furnace performance, Richter and Mitchell [7] concluded that knowledge of particle temperature (which, as they correctly stated, can easily exceed the maximum gas temperature in the flame zone by $350 \mathrm{~K}$ ) is important for evaluation of slagging and fouling tendencies as well as for predictions of furnace heat transfer and carbon burnout. This review paper aims at contrasting the combustion characteristics of coals from various ranks and it also includes limited data on corresponding characteristics of biomasses. Both qualitative and quantitative comparisons are given on various time-dependent phenomena that take place during combustion of these fuels.

Coals are typically classified into four different ranks, lignite, sub-bituminous, bituminous, and anthracite coals. This classification is based on the history of coal formation [2]. Coal originated from peat or partially-decomposed plant materials. Increased pressure and heat from

78 overlaying strata caused peat to dry and harden into lignite, which typically has high contents of 
moisture and ash and low heating value. Under higher pressure, peat formed the higher rank sub-bituminous coal. Even higher pressure resulted in the formation of bituminous or soft coal, having a higher heating value fuel. At elevated pressures, encountered in folded rock strata during creation of mountain ranges, the anthracites or hard coals were generated, possessing the highest heating values and the lowest amounts of moisture and ash than other coal types. Low rank coals contain less carbon in their structure than high rank coals. Biomass, the newest plant-based fuel, contains the least amount of carbon.

Several coals, representative of the aforesaid ranks, have been burned at the laboratory of the authors under identical high-temperature high-heating rate operating conditions and their combustion behavior has been observed at the particle level [8-16]; past results therefrom are reviewed herein and some new results are included. Pertinent results reported in studies conducted elsewhere are also reviewed and compared, however operating conditions therein varied and thus results are not always comparable. Some of those studies were conducted in electrically-heated drop-tube furnaces (DTF), whereas others were conducted in entrained flow reactors (EFR) where streams of coal particles were injected in effluents of combustion of gaseous fuels. Drop-tube furnaces or entrained flow reactors are considered to reproduce conditions that are suitable to those in practical systems, while providing relatively simple and low-cost configurations [17-19].

Depending on the rank of coal, the geographical origin and the seam as well as the operating conditions, such as the particle size, the heating rate in the furnace, the stoichiometry and the mixing rate, the volatile matter evolution and homogeneous combustion, and the heterogeneous combustion of the solid residue may occur separately or simultaneously [20, 21]. In the early stages of combustion, a coal particle reaches sufficiently-high temperatures to release volatile matter, which surrounds the surface of the particle forming tar, soot, light hydrocarbons and hydrogen [22-27]. As devolatilizing gases diffuse/transport from the particle interior to its surface they cause swelling in bituminous coals [28; 25, 29, 8] or fragmentation in low rank coals $[11 ; 25,30]$. Such phenomena provide clear examples of how the devolatilization processes of coal types differ, based on the coal rank [30; 24, 31-34]. Seeker et al. [35] and McLean et al. [36] published photographic evidence on the combustion behavior of bituminous and lignite coals at the Sandia laboratories' laminar flow reactor, whereas Timothy et al. [37] provided photographic evidence and quantitative information on the formation and characteristics of volatile flames (soot mantles) surrounding bituminous coal particles in a DTF. Sarofim, Beer and co-workers pioneered a two-color pyrometric technique that enabled them to gather further information on temperatures and burnout profiles of single lignite and bituminous coal particles burning in a DTF at various oxygen partial pressures in nitrogen [38]. Hernberg et al. [79] reported that pyrometric temperatures of coal beds agreed with temperatures from thermocouple readings. Atal and Levendis [8] obtained high-speed cinematographic images as well as three-color pyrometric temperatures and burnout times of single bituminous coal particles burning in a DTF in air, where the volatile flame and char combustion phases were resolved and assessed. This was followed by recent studies at the authors' laboratory on the qualitative and quantitative ignition and combustion behavior of single coal particles in a DTF, at oxygen partial pressures spanning $20-100 \%$ in nitrogen or 
carbon dioxide background gases, the later used to simulate dry oxy-combustion [10-16]. This was complemented by modeling of relevant combustion phenomena observed in the aforesaid studies [39]. In parallel investigations, Shaddix and co-workers used the Sandia laminar entrained flow reactor to conduct comprehensive studies on the combustion of coals and chars of various ranks at oxygen partial pressures spanning $12-36 \%$, in nitrogen and carbon dioxide [40-42]. Concurrently, Zhang et al. $[43,44]$ studied the combustion behavior of streams of a Victorian brown coal in a DTF, whereas Kim and coworkers [45] examined the combustion characteristics of sub-bituminous coals. Recently, Lee and Choi [46] recorded the volatile phase combustion characteristics of bituminous particles as a function of their size.

In the following sections, important findings of single particle investigations are contrasted and discussed. Emphasis is given to results obtained in the laboratory of the authors where operating conditions were kept identical. Therein pulverized coal particles of all ranks were burned in the same apparatus, an electrically-heated drop tube furnace (TDF) and associated diagnostic methods, under analogous gas temperature, gas flow properties (quiescent), similar particle sizes, etc. [13-15, 39, 47]. The burned coals included one anthracite (herein labeled An) from Asturias, Spain (code named AC), one semi-anthracite (herein labeled: S-An) Hullera Vasco Leonesa in León, Spain (code named HVN), three bituminous (Bit1: Pittsburgh \#8, Pennsylvania, USA, (PSOC-1451), Bit2: a South African (SAB), Bit3: a Mexican (UM)), one sub-bituminous (SBit) from River Basin, Wyodak, Wyoming, USA, (DECS-26), and two lignites (Lig1: Titus, Texas, USA, (PSOC-1443) and Lig2: Beulah, North Dakota, USA, (DECS-11)). All particles were in the size range $(75-150 \mu \mathrm{m})$, which is relevant to pulverized fuel combustion. A biomass (sugar cane baggasse) (Bio) has been also added here to represent a limiting case for new plant-based fuels. Combustion of biomass particles has been studied at the authors' laboratory in the same apparatus as the coals and under similar conditions [11, 13, 57]. Selected results from the above studies are included herein. Thereafter, comparisons are made with pertinent results obtained elsewhere, most often under different, but yet relevant conditions. However, as the conditions differed in those studies the data could not be included in the plots herein.

\section{Phenomenological Combustion Observations}

\section{(a) Conventional Combustion in Air:} High-speed high-resolution cinematography sequences of single particles 75-150 $\mu \mathrm{m}$ burning in still air (quiescent flow) are shown in Fig. 1. The combustion behaviors of coal particles are strikingly differentiated according to their ranks. Such combustion behaviors affect the residence times and the radiative properties of the particles in the furnace. Anthracite particles ignited heterogeneously and also burned heterogeneously in one phase. Some semi-anthracite particles ignited homogeneously and burned in two phases (a faint volatiles flame followed by char combustion), as shown in Fig. 1, and some ignited heterogeneously and also burned heterogeneously in one phase. All bituminous particles of this size range, from four different sources, ignited homogeneously and burned in two phases (volatiles flame and char combustion). Volatile flames were highly sooty and luminous, most often leading to soot 
161 contrails as the particles settled by gravity. The typical combustion behavior of a North 162 American bituminous coal is shown in Fig.1. Bituminous coal particles from other sources were 163 also tested at the authors' laboratory and were presented in Riaza et al. [15]. The combustion 164 behavior of all bituminous coals was remarkably similar. Some sub-bituminous particles ignited 165 homogeneously and burned in two phases (volatiles flame and char combustion). Some others 166 ignited heterogeneously and burned heterogeneously in one phase. Some experienced rather 167 limited bulk fragmentation during devolatilization. Lignite particles experienced massive pre- or 168 post-ignition fragmentation during devolatilization, depending on their origin, accompanied by 169 occasionally brief and faint volatile flames; this was followed by heterogeneous combustion of 170 the fragments. This is in agreement with the findings of Sweeney and Grow [80], who reported 171 that volatiles combustion does not play an important role in the combustion process of lignites. 172 Recently, Lee and Choi [46] confirmed the extensive fragmentation of lignite coals. Both the 173 timing and the extent of fragmentation also depended on the origin (type) of lignite coal. 174 Combustion behavior of coal particles at the presence of active gas flow, under otherwise with 175 similar to the quiescent flow conditions in the DTF showed no apparent differences [11-13], 176 however ignition was delayed.

177 
Anthracite (An), Asturias, Spain, (AC)

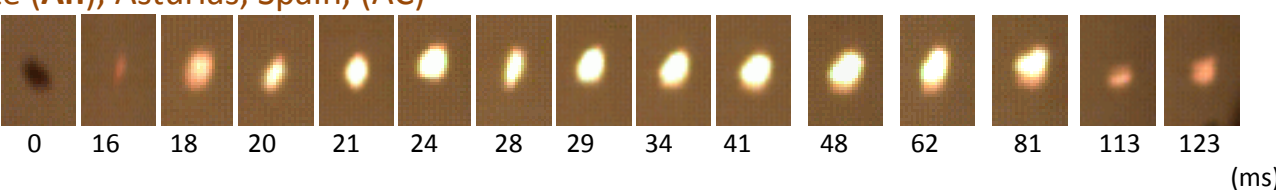

Semi-anthracite (S-An), Hullera Vasco Leonesa in León, Spain, (HVN)
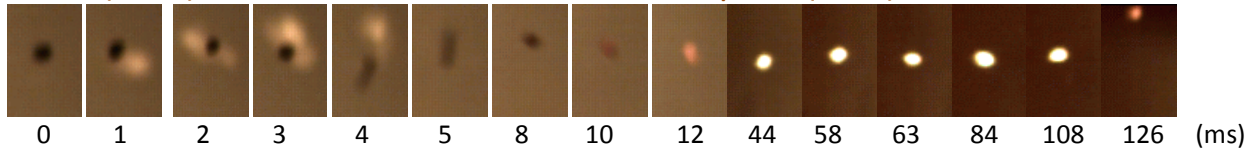

Bituminous (Bit1), Pittsburgh \#8, Pennsylvania, USA, (PSOC-1451)

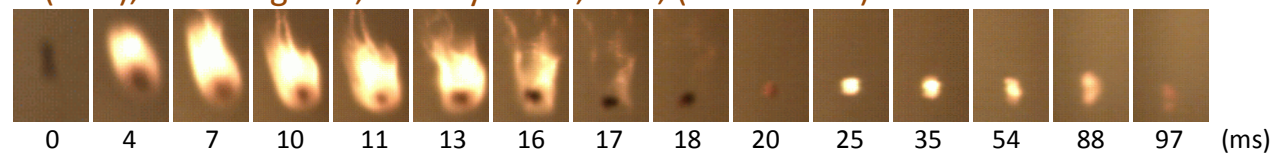

Sub-bituminous (S-Bit), River Basin, Wyodak, Wyoming, USA, (DECS-26)

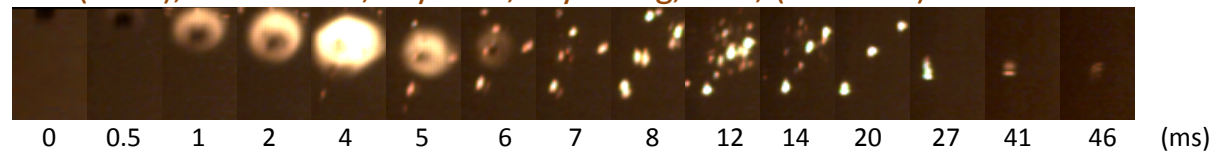

Lignite (Lig1), Titus, Texas, USA, (PSOC-1443)

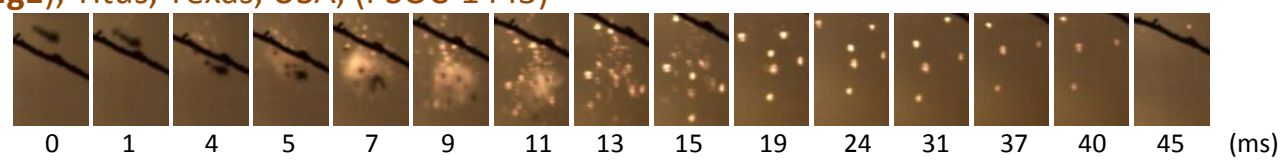

Lignite (Lig2), Beulah, North Dakota, USA, (DECS-11)

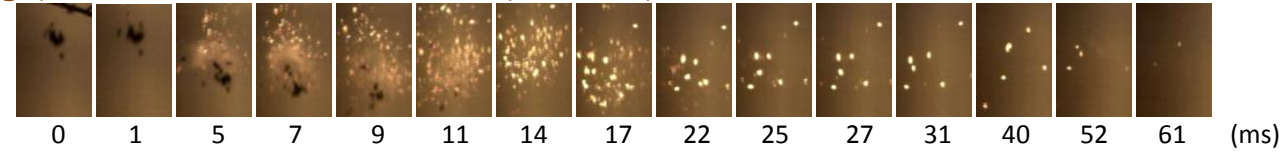

Biomass - sugarcane bagasse (Bio), Brazil
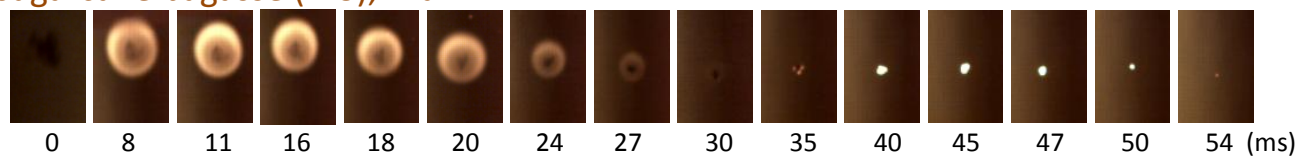

Figure 1. Images from high-speed cinematography of coal particles from various ranks and particles of a biomass (sugarcane bagasse) burning in air in a DTF operated at $T_{\text {wall }}=1400 \mathrm{~K}$ in still air conditions (quiescent flow) in this laboratory [47]. The diameter of the wire shown in some photographs is $100 \mu \mathrm{m}$. The displayed numbers in each frame are in milliseconds, where zero does not mark the beginning of ignition, instead, it merely represents the beginning of the depicted sequences. Nominal particle sizes were in the range of $75-150 \mu \mathrm{m}$.

Elsewhere in the literature, Seeker et al. [35] and McLean et al. [36] showed that volatiles issue from bituminous coal particles as jets, but they do not always form spherically-uniform clouds. Such coals typically swell and form cenospheric chars. In regions where there are no volatile jets, a possibility for heterogeneous surface reaction with oxygen was inferred. No volatile trails were observed for anthracites and lignites and condensed phase matter was not formed. Such coals are non-swelling. These behavioral differences have been attributed to the chemical composition of the coal particles: bituminous volatiles contain soot-producing heavy 
hydrocarbon compounds, whereas lignite volatiles contain mainly $\mathrm{CO}, \mathrm{CO}_{2}, \mathrm{H}_{2}, \mathrm{H} 2 \mathrm{O}$ and light hydrocarbons [48-50]. Ignition and combustion behavior of various coals may vary; for instance, particles of an Australian lignite have been reported to experience heterogeneous combustion before the onset of volatile evolution [51], whereas Leslie et al. [52] reported that, under certain conditions, the combustion of $60 \mu \mathrm{m}$ particles of a Montana lignite coal occurred by direct oxygen attack with little separate evolution of volatiles. Biomass particles burned in two phases; volatile combustion in strikingly-spherical nearly-transparent flames was followed by brief shrinking-core char combustion.

(b) Combustion under Simulated Dry Oxy-fuel conditions:

Coal particles burning in $\mathrm{O}_{2} / \mathrm{CO}_{2}$ atmospheres exhibit similar behaviors (such as mode, sequence and fragmentation) as in air. The main qualitative difference is the lower luminosity of the particles in an $\mathrm{O}_{2} / \mathrm{CO}_{2}$ atmosphere with the same oxygen mole fraction as in air. Quantitative characteristics differ [11-16], as the intensity of particle combustion in $\mathrm{CO}_{2}$ matches that in air only when the oxygen mole fraction is elevated well above $21 \%$. There has been evidence of a coal rank influence on the value of such oxygen mole fraction, as elaborated in an ensuing section of this manuscript.

\section{Ignition Parameters}

\section{(i) Ignition mode}

Anthracite and most of the semi anthracite coal particles ignited heterogeneously while bituminous coal particles from different sources [13-15] ignited homogeneously in the gas phase. As the coal rank decreases to lignite, the ignition mode seems to switch to a mixed heterogeneous/homogeneous behavior $[13,14]$. The increase of fragmentation tendency in the case of lignite coal particles influences such behavior. If fragmentation happens before ignition, the fragments of the lignite coal particles appear to ignite heterogeneously, as particles of small size typically do [54]. However, if the fragmentation happens during or after ignition, then mixed homogeneous/heterogeneous ignition is likely to occur [14]. Biomass particles (bagasse) appeared to ignite homogeneously forming faint spherical flames. Particles of other biomass types were also burned at the authors' laboratory [57] and similar homogeneous ignition behaviors were observed.

(ii) Ignition Temperature

Conventional Combustion in Air: Ignition of the biomass and the low rank coal particles has been observed to be readily achieved; i.e., ignition temperature decreased with decreasing rank. The ignition temperatures were determined based on the temperature gradient method described in Khatami et al. [13]. The ignition temperatures of anthracite, semi anthracite and 
sub-bituminous coals burning in air were also deduced from the experimental pyrometric results in Khatami et al. [13] and Riaza et al. [15], and are shown in Figure 2. For example, under the conditions implemented in this laboratory $[15,16]$, ignition of anthracite occurred at $1300 \mathrm{~K}$ $( \pm 50 \mathrm{~K})$, bituminous at $1200 \mathrm{~K}( \pm 50 \mathrm{~K})$ and lignite coal particles at $1050 \mathrm{~K}( \pm 50 \mathrm{~K})$, whereas ignition of sugarcane bagasse occurred at an estimated $700 \mathrm{~K}( \pm 30 \mathrm{~K})$. The results, shown in Fig. 2 , illustrate a rather monotonic trend of decreasing ignition temperatures with decreasing coal rank. Differences in ignition temperature among the coal ranks can be very significant, amounting to as high as $250 \mathrm{~K}$ for the coals burned in this laboratory. Both the magnitude and the trend of ignition temperatures with the rank of coals (at least for bituminous and lignite coals) is also supported by the theoretical work of Annamalai and Durbetaki [55] and Du et al. [56] for similar conditions and particle sizes. They predicted ignition temperatures to be in the range of $1150-1200 \mathrm{~K}$, for either homogeneous or heterogeneous ignition of bituminous coal particles in air. The ignition temperature of a bituminous coal was also measured to be $1273 \mathrm{~K}$ by Howard and Essenhigh [54] in experiments employing analogous gas temperatures, heating rates and particle sizes. Boukara et al. [81] measured the ignition temperature of a similar size high volatile bituminous char to be $1195 \mathrm{~K}$. Although ignition temperatures were determined with different methods in the literature, the reported values were comparable to those attained at the authors' laboratory. The ignition temperatures of sugarcane bagasse particles were the lowest, most likely due to the high volatile content and light hydrocarbon compositions in their volatile matters. This observation was also valid for other biomass types (pine sawdust, torrefied pine sawdust and olive residues) burned by Riaza et al.[57].

Oxy-fuel combustion: Combustion in higher $\mathrm{O}_{2}$ mole fractions in either $\mathrm{N}_{2}$ or $\mathrm{CO}_{2}$ environments decreases the ignition temperature. For bituminous and lignite coal particles, as $\mathrm{O}_{2}$ mole fraction in $\mathrm{N}_{2}$ increased from 0.2 to 1 , the ignition temperature decreased by $100-150 \mathrm{~K}$ ([13]; Annamalai and Durbetaki[55], Fig. 6a therein; Du and Annamalai[56] see Fig. 8 therein). Wall et al. [58], Zhang et al. [59, 60] and Essenhigh et al. [61], Gururajan et al. [62], Huang et al. [63] reported a similar trend. In $\mathrm{O}_{2} / \mathrm{CO}_{2}$ atmospheres, ignition temperatures of coal particles were observed to be a little higher than those in $\mathrm{O}_{2} / \mathrm{N}_{2}$ [13], at comparable $\mathrm{O}_{2}$ mole fractions. This is in agreement with the findings of Qiao et al. [64], who reported an increase of circa $20 \mathrm{~K}$ at $21 \% \mathrm{O}_{2}$ when $\mathrm{N}_{2}$ was replaced with $\mathrm{CO}_{2}$. 


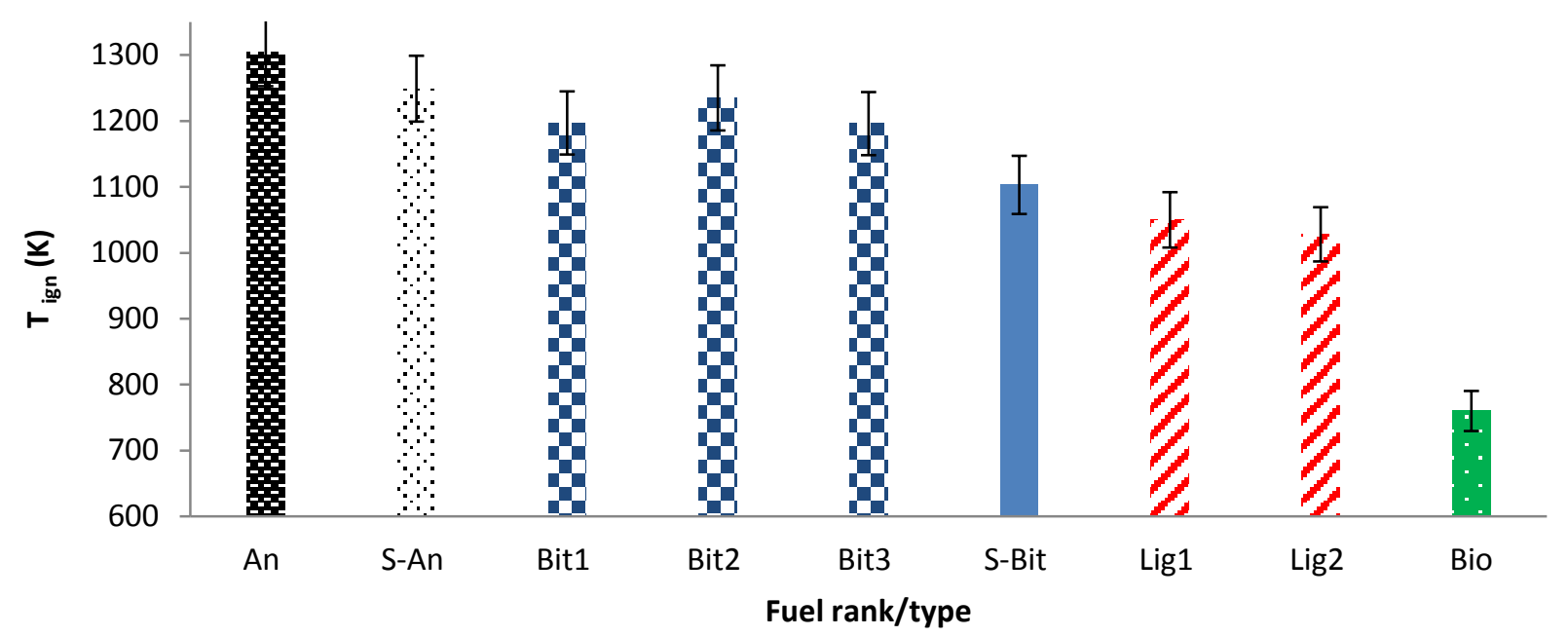

$26 t$

267

268

269

270

271

272

273

274

275

276

277

278

279

280

281

282

283

284

285

286

287

288

289

290

291

292

293

Figure 2. Ignition temperature of coals of various ranks burning in air, as measured in the DTF operated at $T_{\text {wall }}=1400 \mathrm{~K}$ under quiescent flow conditions (no flow). Data was taken from Refs. [11-15]. The coals are listed in the last paragraph of the Introduction Section.

(iii) Ignition Delay Times

The ignition delay, defined in previous work as the time elapsed from a particle's exit from the DTF injector to the moment where it experiences visible ignition in cinematographic images, shows a concave-shaped trend with coal rank (see Khatami et al.[14] for more details). It decreases with decreasing rank, it reaches a minimum in the case of medium rank coals (e.g. bituminous) and then increases again as the rank decreases, as illustrated in Fig. 3. However, the briefest ignition delays were achieved in the case of biomass particles. This was followed by bituminous coal particles. This notable behavior is attributed to the homogeneous mode of ignition exhibited by the bituminous coal and biomass. Heterogeneous ignition tends to increase the delay times. Under the conditions that were implemented in this laboratory, ignition of anthracite particles took $30 \mathrm{~ms}( \pm 7 \mathrm{~ms})$, bituminous $10 \mathrm{~ms}$ ( $\pm 2 \mathrm{~ms}$ ) and lignite particles $15 \mathrm{~ms}$ ( $\pm 4 \mathrm{~ms})[13,14]$, whereas biomass (bagasse) particles ignition delays are in the order of only 1-2 ms. The bituminous coal ignition delay times are in line with those reported by Shaddix and Molina [41] based on extrapolation of their results (i.e., by estimation beyond their reported range of operating parameters). This comparison was performed first by linear interpolation of the results of Shaddix and Molina [41], shown in Fig. 7 therein, which resulted in $6 \mathrm{~ms}$ ignition delay for 75-106 $\mu \mathrm{m}$ Pittsburgh seam bituminous coal particles being heated up at $21 \% \mathrm{O}_{2}$ and $\mathrm{T}_{\text {gas }}$ of $1700 \mathrm{~K}$. Thereafter, to compare with the results obtained in the authors' laboratory, it was assumed that if the reactor temperature of Shaddix and Molina [41] were to be reduced to $1400 \mathrm{~K}$, the ignition delay would be significantly longer, and that would bring it in line with the aforementioned 10 ms duration. The bituminous coal ignition times are also in line with the particle heatup times reported by Lee and Choi [46]. General agreement also seems to 
be obtained with the numerical calculations by Lau and Niksa [65, 66], for Pittsburgh \#8 coal, again upon extrapolation, to the conditions used in the authors' laboratory. For instance, Lau and Niksa $[65,66]$ numerically predicted that a $70 \mu \mathrm{m}$ particle would experience an ignition delay of $\sim 5 \mathrm{~ms}$, at $\mathrm{T}_{\text {gas }}=1500 \mathrm{~K}, 15 \%$ oxygen. Similarly, experimental ignition delay times for a bituminous coal particle 75-90 $\mu \mathrm{m}$, measured by Lee and Choi [46] at $\mathrm{T}_{\text {gas }} \sim 1200 \mathrm{~K}$ were $5 \mathrm{~ms}$. Finally, it should be emphasized that the presence of active furnace gas flow significantly increases ignition delay times; the higher the injector gas flowrate the longer the particle ignition delay [13].

Under simulated dry oxy-fuel combustion conditions (in $\mathrm{O}_{2} / \mathrm{CO}_{2}$ gases), the ignition delay times decrease drastically as oxygen mole fraction increases beyond the air level (21\%) to 100\% [14, $40,46,67]$. Furthermore, ignition delay times are higher in $\mathrm{CO}_{2}$ environments than in $\mathrm{N}_{2}$ environments with the same $\mathrm{O}_{2}$ mole fraction level, due to the higher heat capacity of $\mathrm{CO}_{2}$ and lower diffusivity of $\mathrm{O}_{2}$ in $\mathrm{CO}_{2}[39,41,43]$.

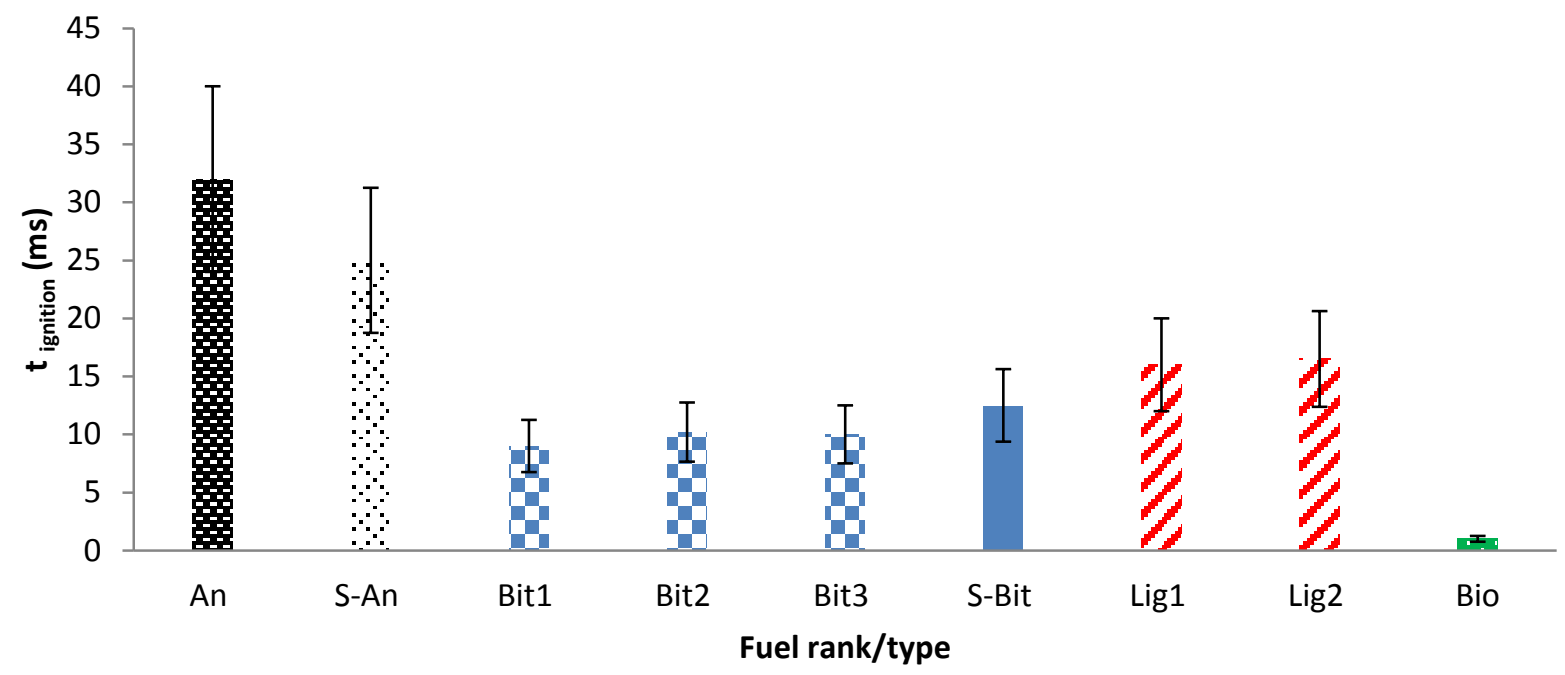

Figure 3. Ignition delay times of coals of various ranks burning in air, as measured in the DTF operated at $T_{\text {wall }}=1400 \mathrm{~K}$ under quiescent flow conditions (no flow). Data was taken from Refs. [11-15].

\section{Combustion Parameters}

\section{(i) Flame temperatures}

Volatile-matter-fueled envelope flames were present in all cases of bituminous coal particles as well as in a number of cases of semi-anthracite and sub-bituminous coal particles $[13,15]$. The results shown in Fig. 4, illustrate a complex-shaped trend of particle envelope flame temperatures (soot mantle temperatures) with a rather unclear dependence on the rank. Under the conditions of past work in this laboratory, flame temperatures of semi-anthracite 
particles were deduced to be approx. $2000 \mathrm{~K}( \pm 100 \mathrm{~K})$, those of bituminous particles varying from $2000 \mathrm{~K}$ to $2270 \mathrm{~K}$ ( $\pm 100 \mathrm{~K})$, depending on the particular coal, whereas those of subbituminous particles were $2100 \mathrm{~K}( \pm 100 \mathrm{~K})$. Biomass volatile generated low-luminosity low-soot content flames, whose radiative intensity could be hardly detected pyrometrically, and temperatures have yet to be reliably determined, thus, this subject merits future research. Relevant supporting observations have been made in biodiesel combustion, in contrast to that petroleum-based diesel oil. The particulate matter from combustion of biodiesels has been shown to be drastically reduced in size and number concentration and, thus, in volume [82, 83, 84]. Information on soot mantle temperatures of burning coal particles is rare in the literature. Shaddix and Molina [41] reported measured soot cloud temperatures for their Pittsburgh bituminous coal that, upon extrapolation of their reactor, gas temperatures and oxygen concentrations to those of the studies in the authors' laboratory, appear to be lower than the corresponding value given above; a linear extrapolation in Fig. 5 of the aforementioned paper resulted in a soot temperature of $\sim 2000 \mathrm{~K}$, at $21 \% \mathrm{O}_{2}, \mathrm{~T}_{\text {gas }}=1700 \mathrm{~K}$. However, those authors mentioned that their assumption of optically thick emission source for such flames may have led to some underestimation in the soot temperatures. At any rate, exact comparisons are not possible, as experimental conditions differ. On the other hand, numerical calculations by Lau and Niksa [66] of the soot mantle temperatures of the Pittsburgh bituminous coal produced values that appear to be somewhat higher (they numerically predicted a peak of $2700 \mathrm{~K}$ at $15 \%$ $\mathrm{O}_{2}, \mathrm{~T}_{\text {furnace }}=1500 \mathrm{~K}$ for a $70 \mu \mathrm{m}$ particle) than the aforementioned value of $2270 \mathrm{~K}$, again upon extrapolation to the conditions used in the authors' laboratory. In this case, the boundary conditions used in those calculations differed from the experimental settings used at the authors' laboratory. Finally, it is noted for comparison that the overall measured temperatures of large multi-particle flames have been reported to be in the range of $1600-2000 \mathrm{~K}[85,86]$.

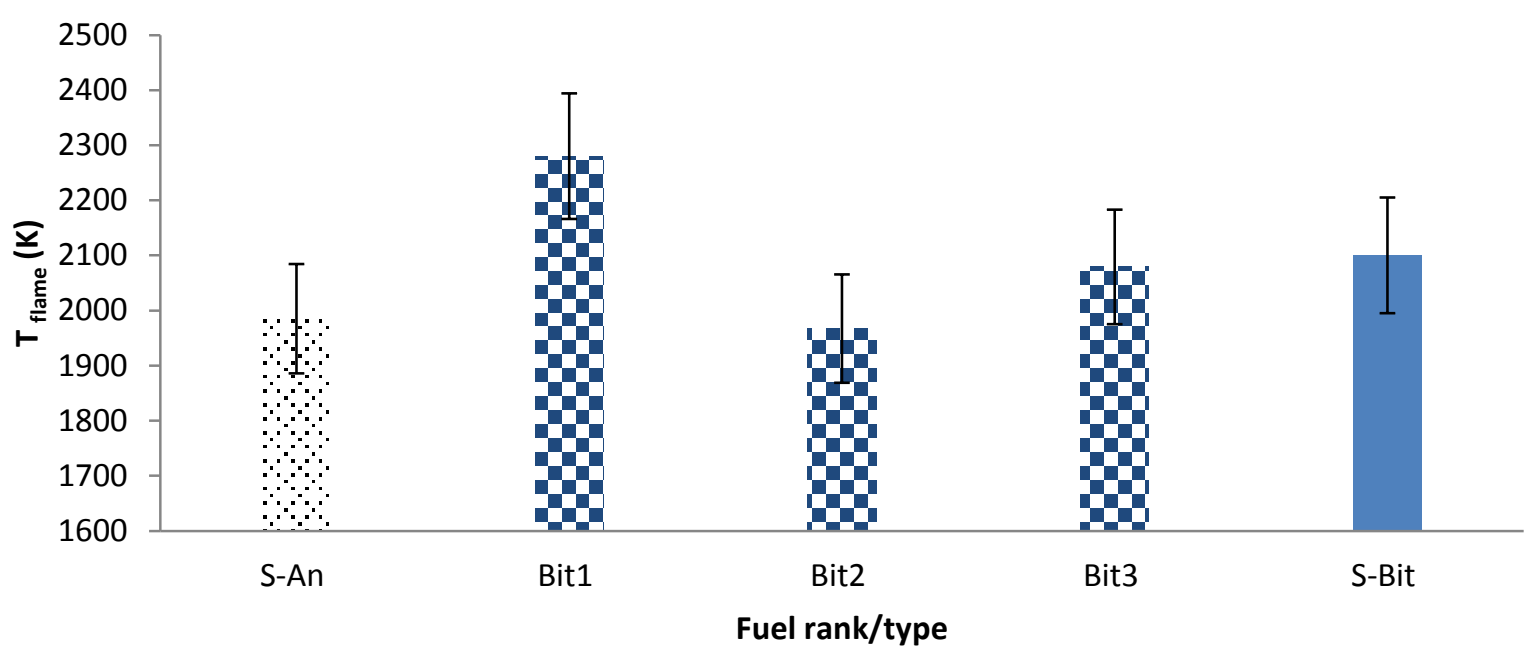

Figure 4. Peak pyrometric envelope flame temperatures of coals of various ranks burning in air, as measured in the DTF operated at $T_{\text {wall }}=1400 \mathrm{~K}$ under quiescent flow conditions (no flow). Data was taken from Refs. [11-15]. 


\section{(ii) Flame burnout durations}

The results shown in Fig. 5, illustrate a convex-shaped trend for the coals, increasing and then decreasing envelope flame durations with decreasing coal rank. Under the conditions of Khatami et al. [13] and Riaza et al. [15], the flame durations of semi-anthracite particles were brief, approx. $4 \mathrm{~ms}( \pm 1 \mathrm{~s})$, those of bituminous particles were $10 \mathrm{~ms}( \pm 2 \mathrm{~ms})$, whereas those of sub-bituminous particles were $9 \mathrm{~ms}( \pm 2 \mathrm{~ms})$. Sugarcane bagasse volatile flame burnout durations were measured using high speed cinematography and were the longest, at $35 \mathrm{~ms}( \pm 5$ $\mathrm{ms})$, as it contains the most volatile matter. Long volatile matter flame durations are typical of biomass particles [57]. The coal volatile flame durations are in line with those reported by Shaddix and Molina [41] for a same origin bituminous coal at extrapolated similar reactor gas temperatures and oxygen concentrations (a linear extrapolation in Fig. 7 of the aforementioned paper resulted in devolatilization periods of $9 \mathrm{~ms}$ for bituminous Pitssburgh\#8 particles burning at $21 \% \mathrm{O}_{2}, \mathrm{~T}_{\text {gas }}=1700 \mathrm{~K}$ ). Devolatilization times reported by Timothy et al. $[37,38]$ for bituminous particles (Illinois \# 6) as well as times reported by Lee and Choi [46] are also in agreement. Overall, satisfactory agreement to some degree is also seen with the numerical calculations by Lau and Niksa $[65,66]$ for a $100 \mu \mathrm{m}$ bituminous coal particle (they predicted a flame duration of $6.5 \mathrm{~ms}$ at $21 \% \mathrm{O}_{2}, \mathrm{~T}_{\text {furnace }}=1250 \mathrm{~K}$ ), again upon extrapolation to the higher temperature conditions that were used at the authors' laboratory.

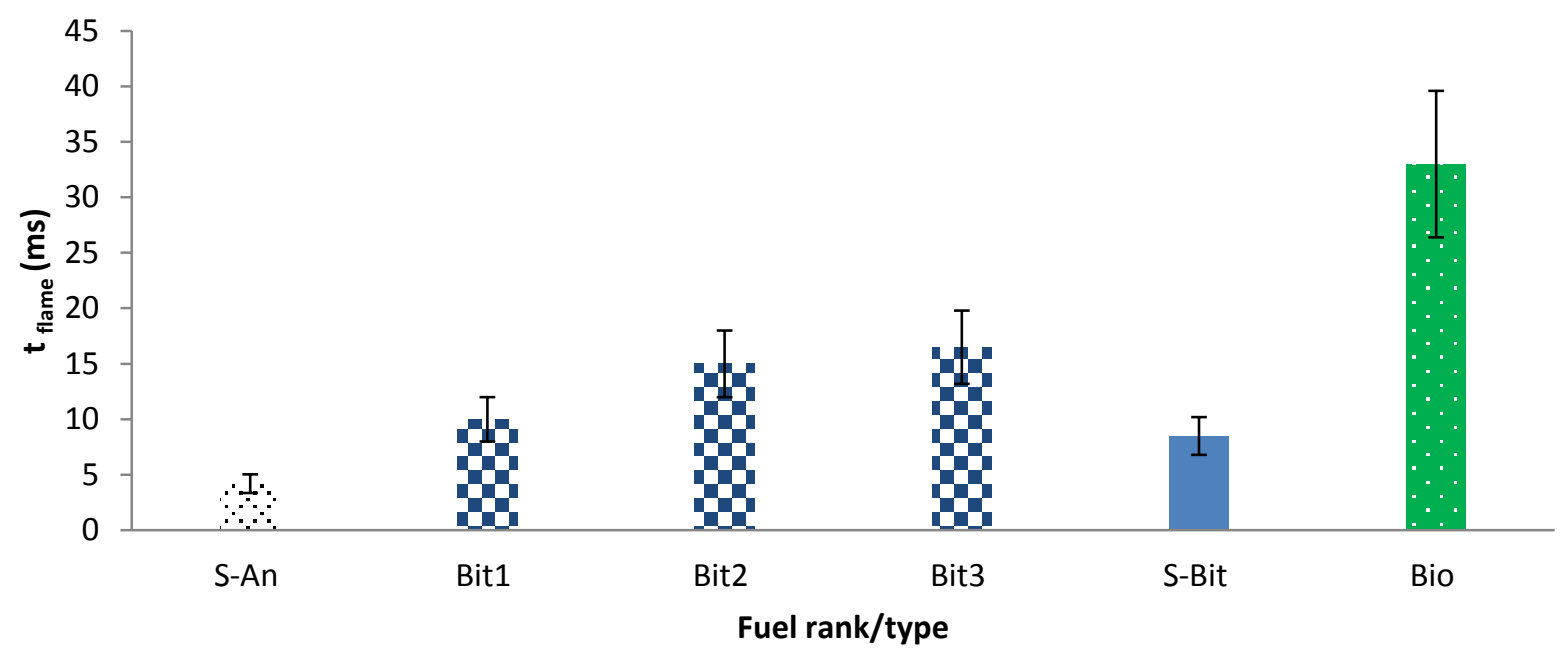

Figure 5. Envelope flame burnout times of coals of various ranks burning in air, as measured in the DTF operated at $T_{\text {wall }}=1400 \mathrm{~K}$ under quiescent flow conditions (no flow). Data taken from Refs. [11-15].

When the flame temperatures and burnout times, shown in Figures 4 and 5, are considered together, it becomes evident that the volatile matter flames enveloping bituminous coal particles are longer-lasting than flames of coal particles of other ranks while they are paradoxically hotter. This noteworthy phenomenon may be explained based on the chemical nature of bituminous coal pyrolyzates (mostly tars and light hydrocarbons, such as $\mathrm{CH}_{4}, \mathrm{C}_{2} \mathrm{H}_{4}$, $\mathrm{C}_{2} \mathrm{H}_{6}, \mathrm{C}_{3} \mathrm{H}_{6}, \mathrm{C}_{3} \mathrm{H}_{8}$, etc., see Suuberg et al. [48], Solomon and Colket [49], Freihaut et al. [50]) that generate more soot than flames of other coals, which typically contain mostly light volatile 
hydrocarbons and $\mathrm{CO}$. Soot needs more time to burn than gaseous hydrocarbon components and, therefore, these flames last longer. The temperature difference is most likely due to a complicated function of the amount of volatiles, the rate of devolatilization, the nature of the release (as jets etc.) and the concomitant intensity of boundary layer mixing with oxygen, the radiating properties of the flame, etc. This subject merits future research.

In simulated oxy-fuel combustion conditions $\left(\mathrm{O}_{2} / \mathrm{CO}_{2}\right.$ mixtures), the volatile flame durations are drastically shortened as oxygen mole fraction increases beyond the air level (21\%) to 100\% [15], which is also true in $\mathrm{O}_{2} / \mathrm{N}_{2}$ mixtures (see also Murphy and Shaddix [40]; Molina and Shaddix [41], Kim et al. [45], Khatami et al. [16]). The effect of the background gas on the volatile flame duration was not as significant and was not always discernible [67]; lengthier flame durations were observed in the case of bituminous coals burning in $\mathrm{CO}_{2}$ than in $\mathrm{N}_{2}[14,67]$, but this was not observed in the case of sub-bituminous coals burning in $\mathrm{CO}_{2}$.

\section{(iii) Flame size (soot mantle or cloud size)}

Figure 6 shows the peak size of the envelope flame for the fuels which experience discernible volatile flame combustion prior to char oxidation. The flame was viewed pyrometrically from the top of the furnace as the particle moved away from the detector gravimetrically. Hence, the deduced flame size is that of the top view of the particle. To estimate the flame size of the side view of the particle, please see the ensuing section on flame aspect ratio. A limited number of semi-anthracite and sub-bituminous coal particles burned with envelope flame and the flame diameters in Figure 6 are representatives of those particles. Bituminous coals from different rank consistently burn with the envelope flame in air and for the particle size range of this study (75-150 $\mu \mathrm{m})$, their size ranges between 250-310 $\mu \mathrm{m}$. Please note that whereas such flames are not typically spherical as they formed contrails, the diameters recorded herein correspond to the portion of the flames that was somewhat spherical. Bagasse (biomass) particles also formed consistent envelope flames with diameters in the order of $300 \mu \mathrm{m}$. Riaza et al. [57] also observed similar behavior for some other biomass types (pine sawdust and olive residue) with envelope flame diameters in the range 190-280 $\mu \mathrm{m}$. The envelope flame diameter trend shown in Fig. 6 for different fuel ranks also illustrates that the volatile content of the fuel does not affect the flame diameter substantially. In other words, although the sub-bituminous and bituminous coals contain similar amounts of volatile matters in their structure, the flame diameters are usually bigger for bituminous coal particle. Moreover, although bagasse particles have a much higher volatile matter content than bituminous coal particles (often by a factor of 2 ), their flame sizes are only slightly bigger than those of bituminous coal particles (by 5-10\%). 


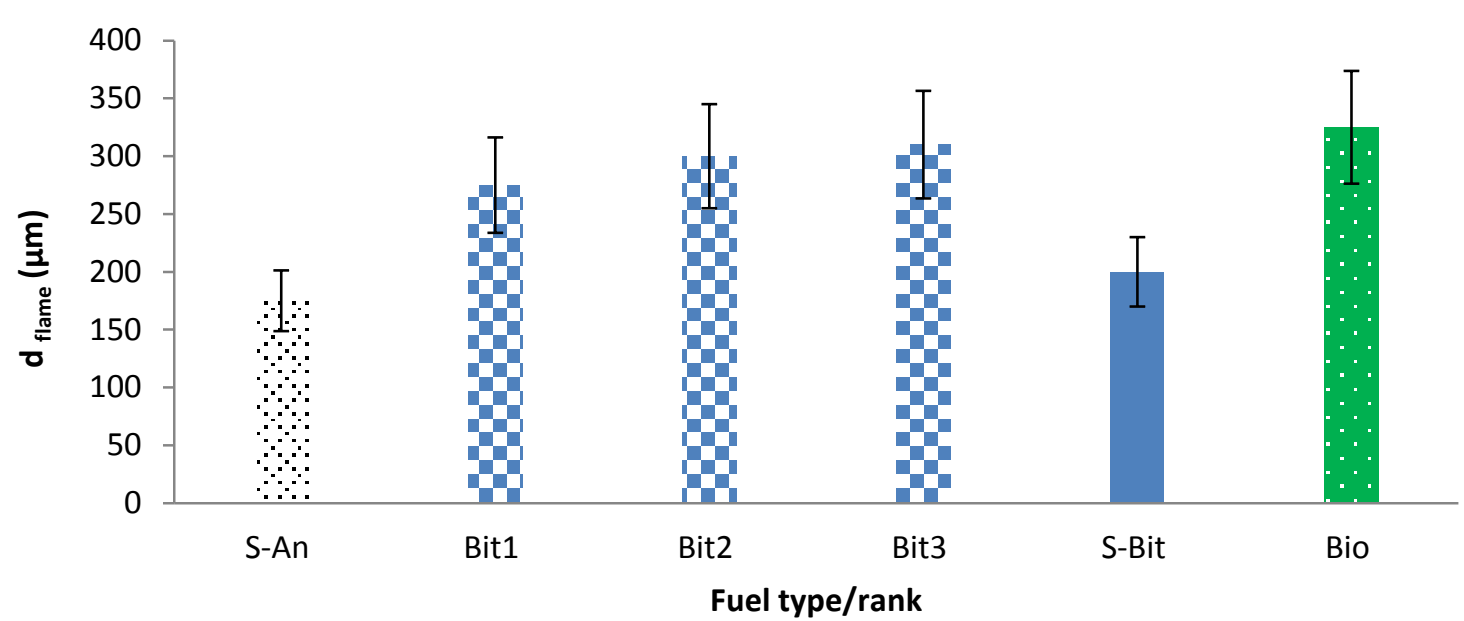

422

423

424

425

426

427

428

429

430

431

432

433

434

435

436

437

438

439

440

441

442

443

444

445

446

447

448

449

450

451

452

Figure 6. Approximate envelope flame diameters of coals of various ranks and biomass (bagasse) burning in air, as measured in the DTF operated at $T_{\text {wall }}=1400 \mathrm{~K}$ under quiescent flow conditions (no flow). Some of the data was taken from Refs. [11-15].

Shaddix and Molina [41], Fig. 5, provided data for 75-106 $\mu \mathrm{m}$ bituminous Pittsburgh \#8 particles burning in $21 \% \mathrm{O}_{2}, \mathrm{~T}_{\text {gas }}=1700 \mathrm{~K}$. Linear interpolation to $21 \%$ oxygen indicates a size of $230 \mu \mathrm{m}$. Their soot cloud size in $\mathrm{CO}_{2}$ was reported to be $280 \mu \mathrm{m}$. The agreement with the author's results is very good, even if a linear interpolation may not be necessary valid. Timothy et al.[37], Fig.6 reported that in air, $1250 \mathrm{~K} \mathrm{~T}_{\text {gas, }}$ Utah bituminous coal 90-105 $\mu \mathrm{m}$ particles have $\mathrm{R}_{\text {flame }} / \mathrm{R}_{\text {particle }}=3.7$, extrapolating for the author's particle size would result in a $D_{\text {flame }}$ of $3.7 \mathrm{x}$ $(75-90 \mu \mathrm{m})=(277-333 \mu \mathrm{m})$. Lee and Choi [46] reported a corresponding ratio of 4-4.5 for a similar size bituminous coal particle burning in air. Furthermore, corresponding ratios for subbituminous coals were appeared to be smaller in the displayed photographs, but the authors did not comment on this. They also showed that the effective flame radius to particle radius decreases with increasing oxygen mole fraction in the gas.

(iv) Aspect ratio of envelope flames

Aspect ratios of volatile envelope flames forming around moving bituminous coal particles, have been shown to vary with the particle size, oxygen mole fraction and particle to gas velocity ratios, among other parameters, Lee and Choi [46]. In experiments where all such parameters were kept constant and similarly-sized particles (75-90 m), fell gravitationally in quiescent flow conditions, at $1400 \mathrm{~K}$ gas temperature, in air, the bituminous coal particles formed the most elongated envelope flames (aspect ratios of 2-2.5:1). Semi-anthracite and subbituminous coal particle envelope flames were spheroidal (aspect ratios of 0.8-1.2:1) and biomass particle flames were perfectly spherical (aspect ratio of $1: 1$ ), see Fig. 1 . The aspect ratios of flames obtained in this laboratory are shown in Fig. 7. It is also worth mentioning that the aspect ratio of bituminous coal increased drastically (aspect ratio of 5:1) in oxy-fuel combustion conditions with similar $\mathrm{O}_{2}$ mole fractions as in air $\left(21 \% \mathrm{O}_{2}\right.$ in $\mathrm{CO}_{2}$ atmosphere). 


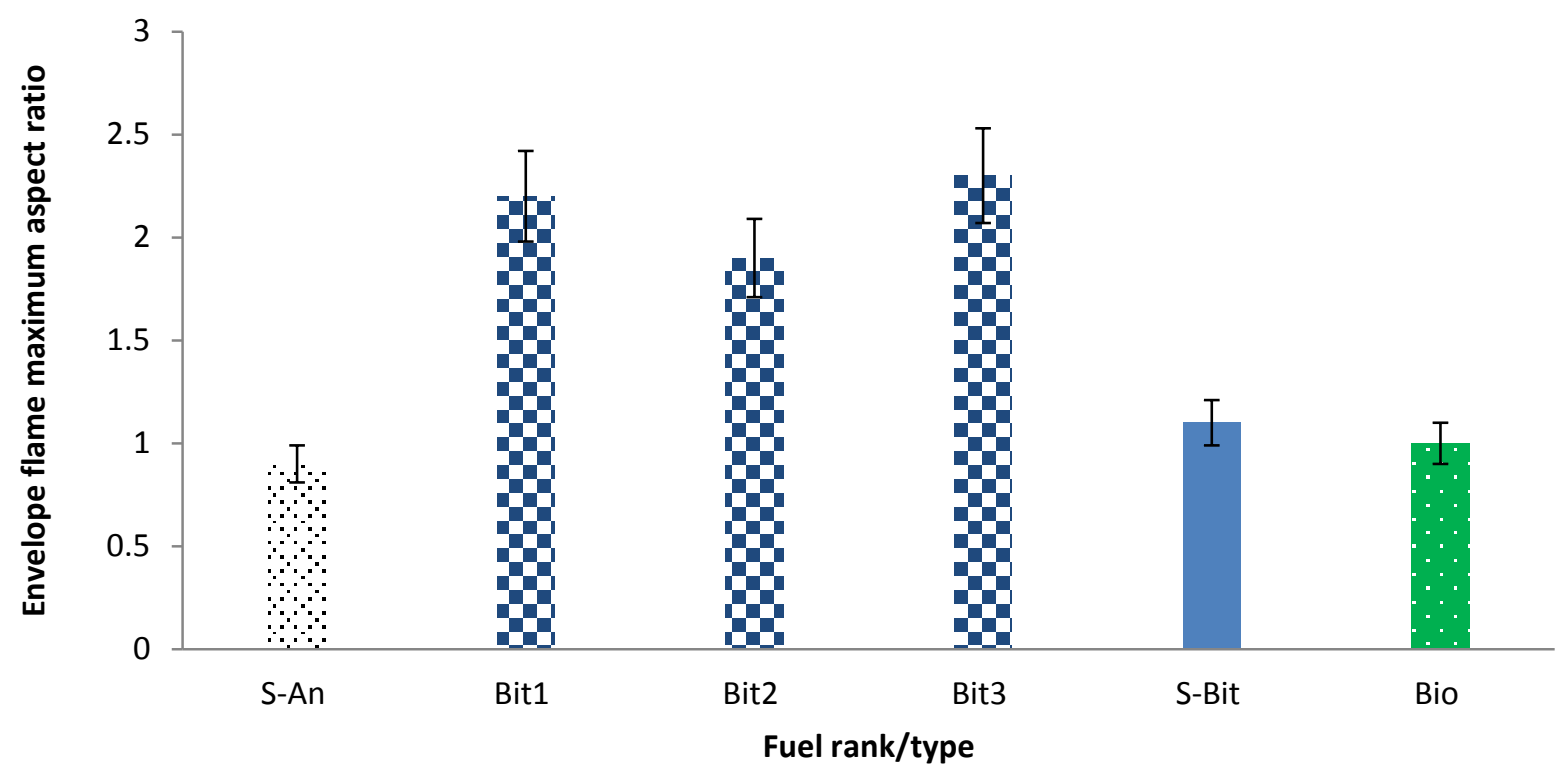

Figure 7. Envelope flame maximum aspect ratio of coals of various ranks burning in air, as measured in the DTF operated at $T_{\text {wall }}=1400 \mathrm{~K}$ under quiescent flow conditions (no flow).

\section{(v) Char temperatures}

The results shown in Fig. 8, illustrate a bimodal distribution for residual char temperatures with decreasing coal rank. High rank coals experienced lower, and similar to each other, char temperatures than low rank coals, which also experienced similar to each other char temperatures. Under the conditions of Khatami et al. [13] and Riaza et al. [15], char temperatures of anthracite and semi-anthracite particles were deduced to be approx. $1830 \mathrm{~K}( \pm$ $70 \mathrm{~K})$ and those of bituminous particles were $1700-1800 \mathrm{~K}( \pm 100 \mathrm{~K})$, whereas those of subbituminous particles were $2100 \mathrm{~K}( \pm 70 \mathrm{~K})$ and those of the lignite particles were $2050 \mathrm{~K}( \pm 70 \mathrm{~K})$. Parenthetically, a study on particle-to-particle temperature variability measured with two distinctly different pyrometric setups was recently published by Schiemann et al. [87]. The higher temperatures of the chars of the low rank coals may be attributed to both their chemical and physical structural properties that affect their reaction rates, as discussed in the ensuing section. Biomass (bagasse) char temperatures have been observed to be $1900 \mathrm{~K}( \pm 70 \mathrm{~K}$ ) which are lower than lignite char temperatures but higher than those of bituminous chars; chars of other types of biomass experienced similar or lower temperatures [57].

Moreover, the cases of the low rank coals (mostly the lignite and partially the sub-bituminous coals) fragmenting to small particles with diameters smaller than a respective critical diameter (as defined by Howard and Essenhigh[54]), signify the occurrence of simultaneous combustion of volatiles and the chars (as calculated by Khatami et al. [13]). Simultaneous combustion of volatiles on char surfaces may result in elevated observed char surface temperatures. Shaddix et al. [68] also documented a similar effect of coal rank on char temperature, where lignite and subbituminous char temperatures were nearly identical, whereas those of bituminous coal chars were lower (by 100-250 K). The aforesaid temperatures of the bituminous and lignite coal 
495

chars observed at the authors' laboratory appear to be in overall agreement with temperatures, again upon extrapolation for furnace temperature, of Beulah lignite chars and Pittsburgh \# 8 bituminous chars burned in the study of Shaddix et al. [68], as well as those of a sub-bituminous coal burned by Shaddix and Molina [41] in an entrained flow reactor. However, anthracite temperatures measured by Shaddix et al. [68] appear to be lower than those mentioned above. Timothy et al. [37] reported similar temperatures for a lignite coal (2000 K) but, surprisingly, they reported higher char temperatures for a bituminous coal (2300 K). The particular bituminous coal is the US coal Illinois \#6 and will be the subject of a future investigation in this laboratory. The aforementioned char temperatures of the sub-bituminous coal particles are higher than those of an Australian sub-bituminous coal (1850-1900 K) burned in an entrained flow reactor by Mitchell and McLean [23]. Again, exact comparisons with different studies are not possible, as both coal properties and experimental conditions differ.

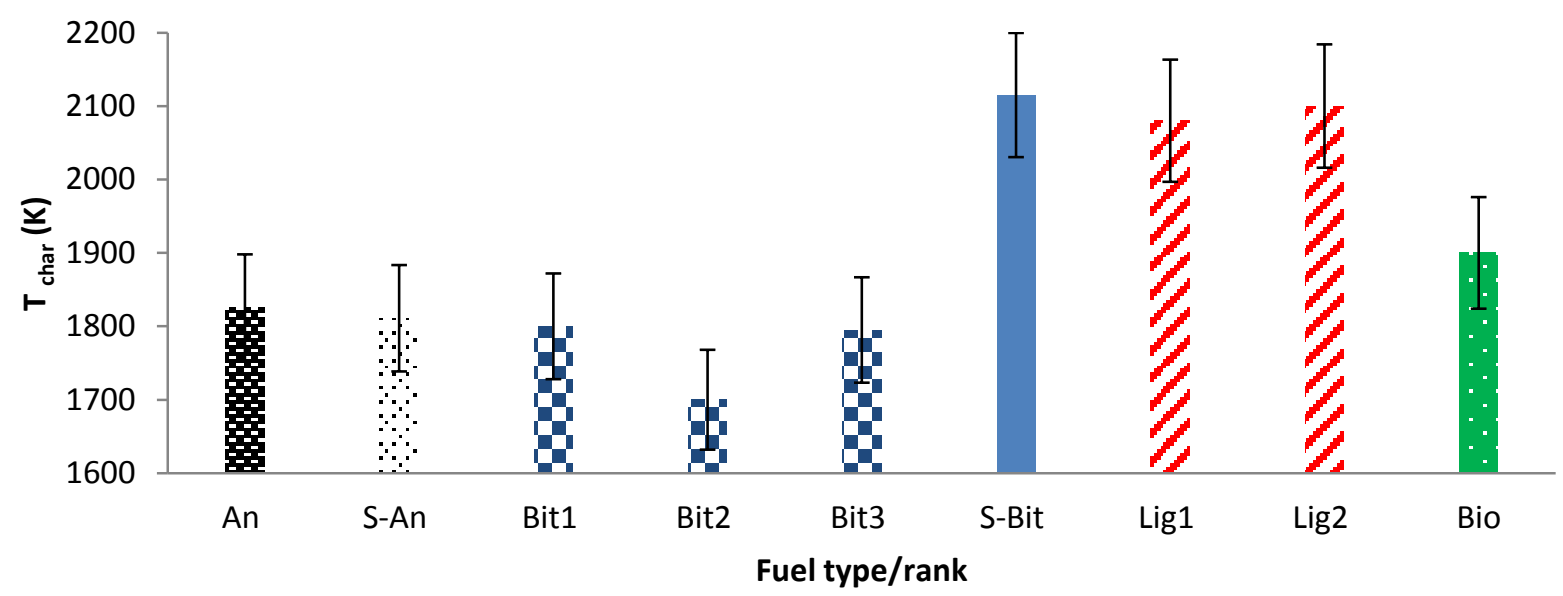

Figure 8. Peak pyrometric char particle temperatures of coals of various ranks burning in air, as measured in the DTF operated at $T_{\text {wall }}=1400 \mathrm{~K}$ under quiescent flow conditions (no flow). Data taken from Refs. [11-15].

\section{(vi) Char Combustion Durations}

The results shown in Fig. 9, illustrate a striking nearly monotonic trend of decreasing char combustion durations with decreasing coal rank. This is related to the fact that char conversion rates have been known to increase with decreasing rank, due to both physical factors (such as fragmentation, etc.), as well as chemical factors (such as catalytic effects of the ashes, see for instance the effects of calcium as reported by Levendis et al.[69]). Indeed, Field [70], Mitchell [28], and Hurt and Mitchell [30] reported that the reactivity of chars increases several fold as the rank decreases from anthracite to lignite. This conclusion has also been supported by Joustenoja et al. [25] and more recently by Shaddix et al. [68]. Moreover, Hurt and Mitchell [30] presented unified high-temperature char combustion kinetics for a number of coals of various ranks and illustrated that their apparent reactivity decreases with increasing rank of the parent coal; or in other words it correlates inversely with the carbon content of coals. Under the 
conditions implemented in this laboratory [14, 16], burnout times of anthracite char particles were monitored to be $280 \mathrm{~ms}$ ( $\pm 25 \mathrm{~ms}$ ), those of semi-anthracite particles were $210 \mathrm{~ms}$ ( \pm 20 $\mathrm{ms})$, those of bituminous particles were $90-100 \mathrm{~ms}( \pm 8 \mathrm{~ms}$ ), those of sub-bituminous particles were $60 \mathrm{~ms}$ ( $\pm 5 \mathrm{~ms}$ ) and, finally, those of lignite coal particles were $60-70 \mathrm{~ms}( \pm 5 \mathrm{~ms}$ ). Biomass char burnout durations were considerably low at $15 \mathrm{~ms}$ ( $\pm 5 \mathrm{~ms}$ ), as evidenced for the sugarcane baggase and some other biomasses [57]. The burnout times of the coals and biomass indeed correlate inversely with their carbon content, particularly with their fixed carbon content, as listed by Khatami et al. [13, 14] and Riaza et al. [15]. The char burnout time durations are in the range of those reported by Timothy et al.[38]; however, in that study the burnout times of a lignite coal char were curiously longer than those of a bituminous coal char, consistent with their aforementioned lower observed temperatures for the former.

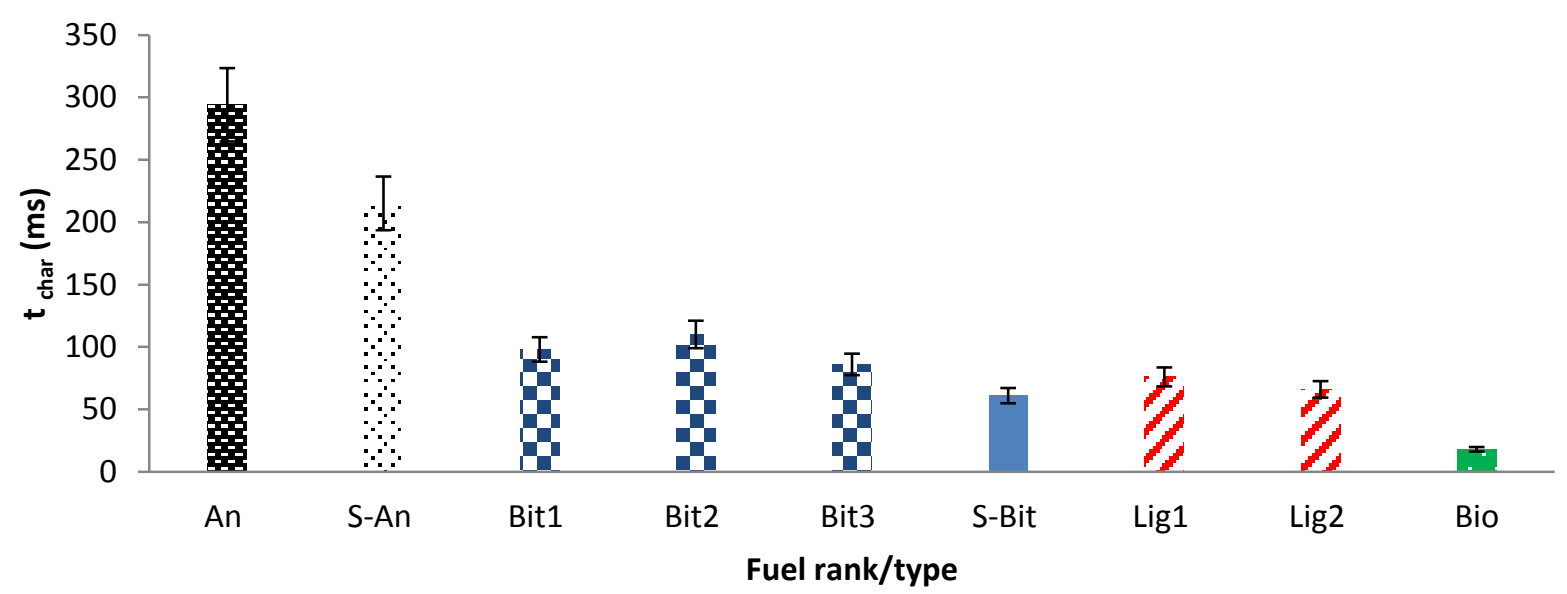

Figure 9. Burnout times of chars of various coal ranks burning in air, as measured in the DTF operated at $T_{\text {wall }}=1400 \mathrm{~K}$ under quiescent flow conditions (no flow). Data adopted from Refs. [11-15].

When combustion of the coals occurs under simulated oxy-fuel conditions $\left(\mathrm{O}_{2} / \mathrm{CO}_{2}\right)$, the flame and char temperatures has been found to be lower and the burnout times to be longer than in $\left(\mathrm{O}_{2} / \mathrm{N}_{2}\right)$ for all coal ranks at comparable $\mathrm{O}_{2}$ mole fractions, see Bejarano et al. [10], Khatami et al. [13] and Riaza et al. [15]. Higher rank coals have been found to typically require more background oxygen in oxy-fuel combustion to match the air combustion condition [13].

\section{(vii) Fragmentation:}

Fragmentation of coals during the devolatilization and the char combustion phases has been observed and studied in the past. Among other researchers, Mitchell and Akatenuk [71] reported that the fragmentation of coals can be classified to occur by either attrition, breakage or percolation and they developed a mathematical model to describe such behaviors. Their modelling results suggested that percolative fragmentation (coal particle fragmentation into a distribution of smaller size particles) may take place during the heat up and devolatilization 
phases of coals with high volatile content and porosity. Their calculations indicated that the rate of fragmentation occurring during heat-up and devolatilization is higher than the rate of fragmentation occurring during the ensuing char oxidation phase. They also concluded that as overall particle burning rates depend on particle size, fragmentation affects such burning rates and should be accounted in pertinent modelling efforts. This was echoed by the findings of Jimènez and Ballester [72] who reported that the increase in specific surface area caused by particle fragmentation increases the conversion (burning) rate and affects drag forces on particles in the furnace. This in turn affects the calculation of particle transfer of mass and heat. Implementation of models that correctly account for fragmentation can improve the accuracy of simulations for industrial furnaces. Under the experimental conditions implemented in the studies that took place at the authors' laboratory $[11,13,15]$ a number of particles of the subbituminous coal experienced bulk fragmentation during their devolatilization phase, whereas all particles of the two lignite coals experienced massive bulk fragmentation during devolatilization (percolative fragmentation) in the DTF, heated to $T_{\text {wall }}=1400 \mathrm{~K}$. One of the two lignites (Beulah) experienced more extensive fragmentation than the other (Wilcox). The fragmentation of the former coal started upon ignition, whereas that of the latter coal started prior to ignition. On the average, those particles of the sub-bituminous coal that fragmented generated 8 ( \pm 2 ) fragments. All Wilcox lignite particles generated on the average $40( \pm 8)$ fragments each, whereas all Beulah lignite particles generated $100( \pm 20)$ particles each, upon bulk fragmentation. Bituminous particles were observed to experience very limited, if any, peripheral fragmentation during devolatilization (Fig. 10).

No fragmentation was observed cinematographically during the char combustion phase. However Baxter [73] observed that during the char combustion phase bituminous cenospheric chars fragment more easily than the compact lignite chars, something that could not be observed in the authors, DTF apparatus, as most likely it occurred during the latest stages of char combustion phase where visible radiation is dim. This is supported by the coal ash studies of Kazanc and Levendis [74], which showed that ash yields from the combustion of the bituminous and of the lignite chars were comparable in the particle size range of 1-5 $\mu \mathrm{m}$. Ashes in this supermicron size range $\left(\mathrm{PM}_{1-5}\right)$ have been associated with the mechanism of coal fragmentation by Helble and Sarofim [75]. This is in contrast to submicron coal ashes $\left(\mathrm{PM}_{1}\right)$, which have been associated with the mechanisms of ash vaporization-nucleation-condensation[76-78]. Such comparable $\mathrm{PM}_{1-5}$ yields perhaps result from the bituminous coals experiencing breakage fragmentation during their char combustion phase (typically up to 100 fragments/particle according to Baxter [73]) and from the lignite coals experiencing percolation fragmentation during their devolatilization phase (up to 100 fragments/particle according to Levendis et al.[11] and Khatami and Levendis [13]. 


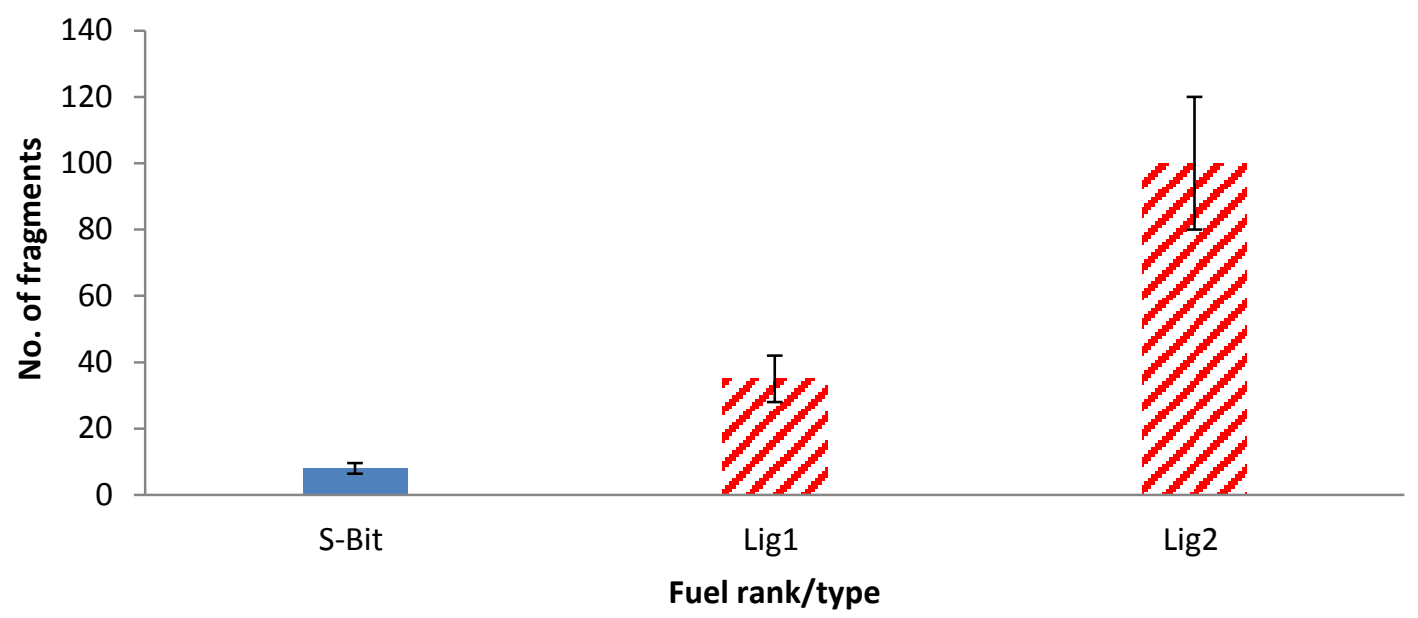

Figure 10. Bulk fragmentation extents of coal particles various ranks burning in air in a DTF operated at $T_{\text {wall }}=1400 \mathrm{~K}$ in quiescent flow conditions (no flow). Data from Refs. [11-15].

To shed additional light on the presence or absence of fragmentation of various types of coals during the devolatilization stage, pyrolysis experiments, in nitrogen at a DTF temperature of $1400 \mathrm{~K}$, were conducted in the authors' laboratory with 75-90 $\mu \mathrm{m}$ coal particles. Selected cases are shown in Fig. 11.
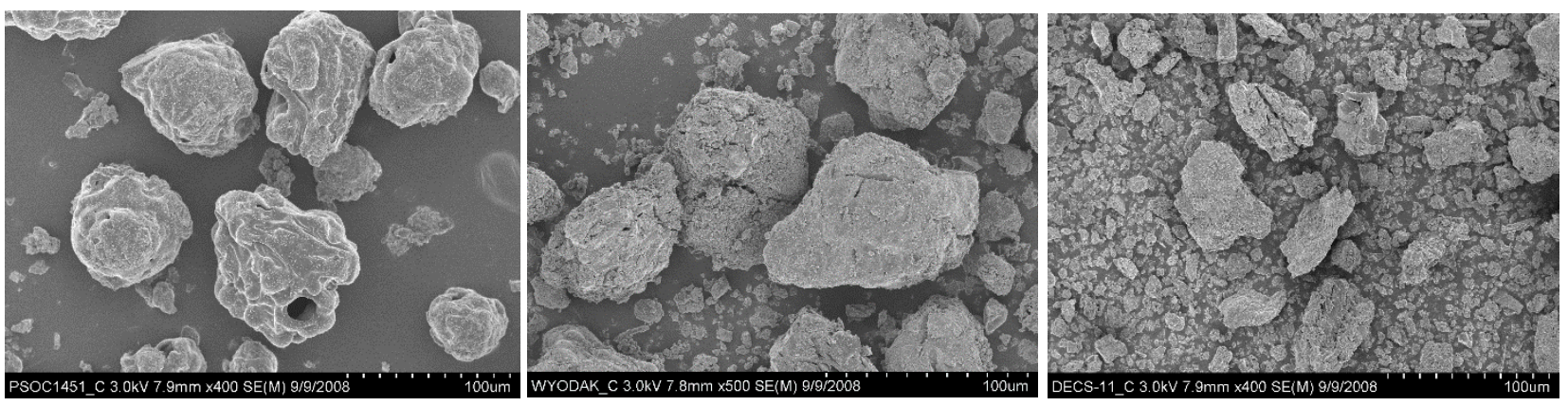

Figure 11. SEM photographs of collected chars upon devolatilization of three coals in an inert $\left(\mathrm{N}_{2}\right)$ atmosphere at $T_{\text {furnace }}=1400 \mathrm{~K}$ : (a) bituminous (Pittsburgh \#8), (b) sub-bituminous (Wyodak) and (c) lignite (Beulah).

These photographs depict coal chars collected at the exit of the furnace, observed under a scanning electron microscope (SEM). In the left frame the reader can see cenospheric chars 597 from a typically swelling bituminous coal, often punctuated by characteristic blowholes. There 598 is evidence of only very limited fragmentation during their devolatilization stage. In the middle 599 frame, chars of a sub-bituminous coal are shown; therein a fair number of fragments is evident, 600 indicative of significant fragmentation. In the right frame chars of lignite chars are shown; 601 numerous small fragments can be seen collected along with few larger particles, attesting to 
massive fragmentation. The large particles are in the order of $50 \mu \mathrm{m}$, whereas the small particles are in the order of $10 \mu \mathrm{m}$. These photographs support the cinematographic observations of the combustion behavior of chars depicted in Fig. 1, and are in line with the fragment populations that appear in Fig. 10.

In oxy-fuel combustion conditions, lignite coal particles were consistently fragmented in either $\mathrm{O}_{2} / \mathrm{N}_{2}$ or $\mathrm{O}_{2} / \mathrm{CO}_{2}$ conditions while some limited fragmentation was also observed in the case of the sub-bituminous coal particles. At higher $\mathrm{O}_{2}$ mole fractions, the number of lignite fragments did not change substantially. However, the number of lignite particle fragments decreased when the $\mathrm{N}_{2}$ background gas was replaced by $\mathrm{CO}_{2}$, perhaps due to the higher heat capacity of the latter gas which, in turn, affects the heating rate of the injected coal particles in the DTF.

\section{(viii) On the Oxygen Partial Pressure Requirement in Oxy-Combustion:}

A number of researchers in the oxy-coal combustion field have investigated the level of oxygen partial pressure in the recycled gases that will be required to simulate conventional air-fired combustion conditions. Such conditions include ignition delay, combustion temperatures, furnace temperature profiles and outlet temperatures, and radiative and convective heat transfer. In a recent review on the subject of oxycombustion of pulverized coals, however, Chen et al. [88] pointed out that the optimal oxygen fraction for a matched temperature is also dependent on the fuel (coal rank, moisture content, etc.), and that this dependence needs further investigations. Hence, this section of the manuscript addresses the effect of the coal rank on the oxygen mole fraction requirement. It reviews both work that was performed at the authors' laboratory after the aforementioned review was written, as well as pertinent work conducted elsewhere.

It should be first mentioned that adiabatic flame temperatures (AFT) based on combustion of various carbonaceous species in $\mathrm{O}_{2} / \mathrm{CO}_{2}$ environments have been shown to match the AFT in air-fired combustion when the oxygen mole fraction is in the range of $(36-42 \%)[10,89,90]$. One of the most important considerations in this determination is whether the recycled flue gases are wet or dry, as their volumetric heat capacities differ. The oxygen requirement is higher in dry than in the wet oxy-combustion ( $35 \%$ vs $28 \%$ based on the calculation of Wall et al. [90]; or $25-35 \%$ vs $23.5-27 \%$ based on experimental findings compiled by Chen et al. [88]).

To follow-up on the suggestion of Chen et al. [88] and investigate the oxygen mole fraction requirement in simulated dry oxy-combustion of coals of different ranks that results in matching the air-fired combustion, peak char combustion temperatures were used herein. This decision was made for consistency, as all the coals and the biomass experienced a char 
637 combustion phase, but only some experienced a volatile combustion phase. This approach is 638 different than that of Khatami and Levendis [13] who took into account combustion 639 temperatures and burnout times of the fuels. It resulted in narrower ranges of data and clearer 640 trends, as shown in Fig. 12. Overall, higher rank coals appear to require more oxygen in a dry $641 \mathrm{CO}_{2}$ environment to match the char combustion temperature-time histories in air $\left(21 \% \mathrm{O}_{2}\right)$. On 642 the other hand, the fuels which have increasingly more oxygen in their structure (lower rank 643 coals and, particularly, biomass) appear to need less ambient oxygen to bring their burning 644 behavior in $\mathrm{O}_{2} / \mathrm{CO}_{2}$ on par with that in air. Apart of the oxygen content of the fuels there may 645 be other factors at play, such as the mode of combustion and the associated combustion 646 Regime (I, II or III, see Ref. [21]) that governs the combustion of the chars or fragments 647 therefrom. The ambient oxygen requirement in dry $\mathrm{CO}_{2}$ gases for the anthracite coals was 648 found to be in the range of $34-36 \%$, for the semi-anthracite coals to be in the range of $33-35 \%$, 649 for the bituminous coals it was found to be in the range of 32-34\%, for the sub-bituminous 650 coals to be in the range of $32-34 \%$, for the lignite coals to be in the range of $30-32 \%$, and for 651 several examined biomasses to be in the range of $27-29 \%$. It should be noted that these results 652 are based on a limited number of coals and biomasses and trends cannot be necessarily 653 generalized.

654

Prior relevant investigations in the literature were conducted by burning an assortment of coals (mostly bituminous and some times of non-specified ranks) and used a variety of criteria and 657 experimental approaches to determine the mole fraction of oxygen in carbon dioxide to match 658 combustion in air (21\% oxygen in nitrogen). In the following they will be organized based on the 659 coal rank (Fig. 12).

(a) Bituminous coal: Wang et al. [91] reported that $31 \% \mathrm{O}_{2}$ in $\mathrm{CO}_{2}$ is needed to result in furnace 661 temperatures similar to those achieved in air-fired combustion. Kimura et al. [89] reported that $66231+\% \mathrm{O}_{2}$ is required based on the amount of unburned carbon in the ash. Upon examination of 663 the results of Kiga et al. [92], see Fig. 3 therein, $35 \% \mathrm{O}_{2}$ appears to be necessary based on the 664 flame propagation speed. Ochs et al. [93] conducted numerical simulations of a boiler 665 operation and concluded that at least $28 \% \mathrm{O}_{2}$ is required to achieve a similar to air-fired steam 666 generation rate. Liu et al. $[53,94]$ reported that $30 \% \mathrm{O}_{2}$ is required to match gas temperature 667 profiles in a laboratory coal-fired combustor. Croiset et al. [95] reported that $35 \% \mathrm{O}_{2}$ is 668 required to match the exit temperature of a laboratory combustor. Tan et al. [96] confirmed 669 the aforementioned finding based on a heat flux analysis. Smart et al. [86] reported that 32$67035 \% \mathrm{O}_{2}$ is required to achieve equivalent flame temperatures. Man et al. [97] and Man and 671 Gibbins [98] reported that $30-35 \% \mathrm{O}_{2}$ is needed to achieve similar to air ignition patterns. 672 Finally, based on the experiments of Shaddix and Molina [41] in an entrained flow reactor at 673 the Sandia Laboratories (Fig. 5 therein), it can be estimated that roughly $25 \%$ and $30 \% \mathrm{O}_{2}$ are 674 required to match the air-fired char and soot mantle temperatures, respectively of a 
675 bituminous coal. It is notable that the Sandia investigators also reported that the oxygen 676 requirement in $\mathrm{CO}_{2}$ to match the char air-fired temperatures increases with the gas 677 temperature of the furnace.

678 (b) Sub-Bituminous coal: Croiset et al. [95] reported that $28 \% \mathrm{O}_{2}$ is required to match the exit 679 temperature of a laboratory combustor.

680 (c) Lignite coal: Zhang et al. [43,44] reported that $27 \% \mathrm{O}_{2}$ is required to maintain equivalent 681 char temperatures for lignite chars. Zhang et al. $[43,44]$ reported that $30 \% \mathrm{O}_{2}$ is needed to 682 achieve similar coal ignition intensity. Anderson et al. [99] and Hjärstam et al. [100] reported 683 that $25 \% \mathrm{O}_{2}$ is needed to achieve similar to air temperature distributions in a laboratory 684 furnace. Based on the results of Shaddix et al. [68] (Fig. 6 therein) it can be estimated that up to $68527 \% \mathrm{O}_{2}$ is needed to match the air-fired char temperatures.

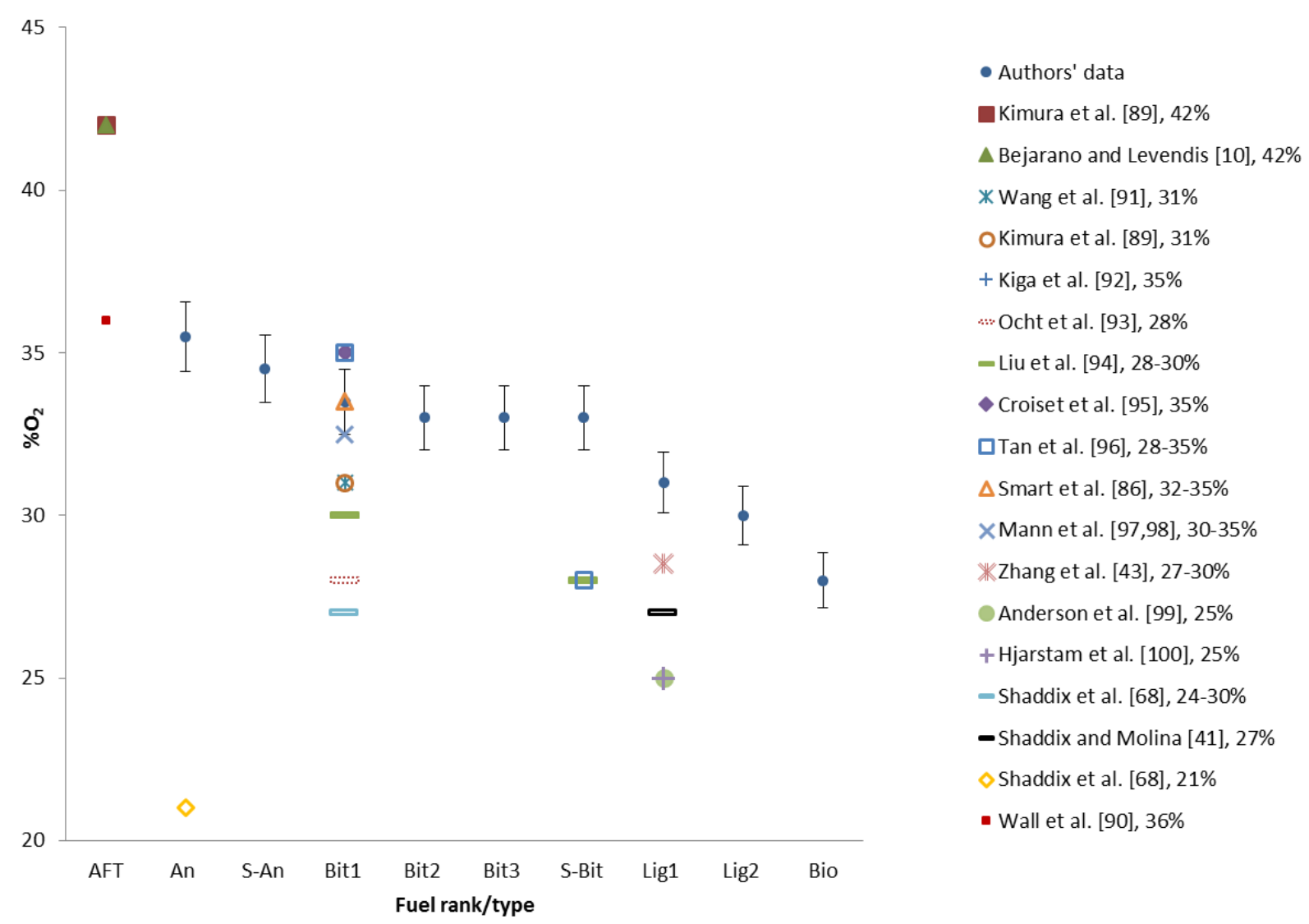

687 Figure 12. Rank-dependent oxygen mole fraction requirement in oxy-fuel combustion. The first column labeled AFT 688 corresponds to Adiabatic Flame Temperature calculations. Numerical values of the reported oxygen concentrations 689 are included in the legend.

690 (d) Anthracite coal: Based on observations on a particular anthracite char, Shaddix et al. [68] 691 (Fig. 6 therein) reported no meaningful differences in the mean particle temperatures 
measured in the $\mathrm{N}_{2}$ and $\mathrm{CO}_{2}$ environments. This rather unexpected behavior may be explained based on the reported fact that this particular anthracite was prone to fragmentation during combustion.

To summarize the above findings, it is evident that coals burning in background carbon dioxide gases, simulating dry one pass oxy-combustion need much higher oxygen mole fractions than in conventional air-fired conditions. With exceptions, the higher the rank of the fuel the higher the oxygen mole fraction requirement.

\section{Summary and Conclusions}

This paper provided an overview of the rank-dependency on the combustion behavior of pulverized coals. It first drew data from past studies in the authors' laboratory that examined the combustion of a variety of pulverized coals, with particles in the nominal range of 75-150 micrometers which is relevant to pulverized coal combustion. The reason that emphasis was given to such data sets, is that combustion of the coals was conducted in the same apparatus and under the same operating conditions. A woody biomass residue (sugarcane bagasse) was also included for comparison. Thereafter, to prove the validity of magnitudes and tends such results were contrasted to those of other coal combustion studies in the literature. The reader, however, should note that in studies elsewhere the coal types, their origins, particle size cuts and the operating combustion conditions varied broadly.

The combustion behaviors of particles in a size range typically used in pulverized fuel combustion $(75-150 \mu \mathrm{m})$ may be summarized as follows:

- Ignition-related observations indicate that all bituminous and some sub-bituminous coal particles experience homogeneous ignition; whereas same size anthracite, semianthracite and lignite coal particles experience mostly heterogeneous ignition.

- Ignition temperatures increase with increasing coal rank. High rank coals, such as anthracite and semi-anthracite, experience lengthier ignition delays whereas low rank coals, such as lignites, experience briefer ignition delays. Biomass, the lowest rank fuel, exhibited the lowest ignition temperature.

- Combustion-related observations indicate that pulverized coal particles burn in either a dual-mode (homogeneous combustion of volatile matter in envelope flames, followed by heterogeneous char oxidation), or in a single-mode (simultaneous burning of volatiles and char), depending on their rank, origin, size and furnace operating conditions. Increasing the coal rank, from lignite to bituminous, enhances the tendency of coal 
particles to exhibit a two-mode combustion behavior. However, increasing the rank further to semi-anthracite and anthracite, reverts the combustion to one mode (char combustion). Woody biomass burned with two-phase combustion mode.

- Bituminous coal particles are the only types that exhibit swelling during devolatilization with concomitant formation of cenospheric chars. Sub-bituminous coal particles exhibit limited bulk fragmentation, whereas lignite coal particles exhibit massive bulk fragmentation during devolatilization, with the onset of fragmentation and its extent depending on the lignite seam. There has been evidence for attrition fragmentation of bituminous coals during the latest stages of char combustion.

- Soot content in volatile envelope flames and, thus, luminosity during combustion increases with fuel rank from lignite to bituminous.

- Combustion temperatures and burnout times of volatiles and chars are affected by coal rank.

- Substitution of the background gas $\mathrm{N}_{2}$ with $\mathrm{CO}_{2}$, to simulate dry oxy-combustion conditions, and keeping the $\mathrm{O}_{2}$ mole fraction the same, lengthens the ignition delay times and mildly increases ignition temperatures; moreover, it drastically lowers the combustion temperatures and prolongs the burnout durations for all coal ranks.

- Oxygen mole fractions in the range of $25-40 \%$ have been reported to be required to achieve comparable combustion intensity parameters in $\mathrm{CO}_{2}$ background gases as in air fired combustion. Generally, the higher the rank of the fuel the more the $\mathrm{O}_{2}$ requirement.

If one considers either substitution or blending of one type of coal with another or with biomass, for the control of emissions of pollutants and greenhouse gases, then knowledge of the combustion characteristics of these fuels can lead to informed decisions.

\section{Acknowledgements}

The authors acknowledge financial assistance from the NSF award CBET-0755431. The authors are thankful to the late Professor Adel F. Sarofim for many valuable discussions. The authors would also like to thank Dr. Juan Riaza and Dr. Fernando Rubiera for the assistance in providing the anthracite and semi-anthracite coals, conduction of the relevant experiments and the technical discussions. 


\section{References}

762

763

764

765

766

767

768

769

770

771

772

773

774

775

776

777

778

779

780

781

782

783

784

785

786

787

788

789

790

791

792

793

794

795

796

797

798

799

800

801

802

803 804

[1] EIA- Annual Energy outlook, 2013 (www.eia.gov)

[2] "Facts about Coal" Published by the National Mining Association, Washington DC, 1995.

[3] BP Energy outlook 2030, 2013.

[4] World Coal Association, http://www.worldcoal.org/coal/uses-of-coal/coal-electricity/.

[5] Shaddix, C. R. "Coal combustion, gasification, and beyond: Developing new technologies for a changing world" Combustion and Flame, 159 (2012) 3003-3006.

[6] STEAM its generation and use, 40th edition, published by Babcok and Wilcox, 1992.

[7] Richter, W., Mitchell R.E., "Effect of True Particle Temperature on Boiler Furnace Performance." Presented at the Fall Meeting of the Western States Section of the Combustion Institute, 1989.

[8] Atal, A. and Levendis, Y.A., Fuel, 74(11) (1995) 1570-1581.

[9] Atal, A., Steciak, J. and Levendis, Y.A., Fuel, 74(4) (1995) 495-506.

[10] Bejarano, P., Levendis, Y.A., Combustion and Flame, 153 (2008) 270-287.

[11] Levendis, Y. A., Joshi, K., Khatami, R., Sarofim, A. F., Combustion \& Flame 158 (2011) $452-465$.

[12] Khatami, R. and Levendis, Y. A., Combustion and Flame 158 (2011) 1822-1836.

[13] Khatami, R., Stivers C., Joshi K., Levendis Y. A. and Sarofim A. F., Combustion and Flame 159 (2012a) 12531271.

[14] Khatami, R., Stivers C., Joshi K., Levendis Y. A., Combustion and Flame, 159 (2012b) 3554-3568.

[15] Riaza, J., Khatami, R., Levendis Y. A., Alvarez, L., Gil, M.V., Pervida, C., Rubiera, F., Pis, J.J., Combustion and Flame 161 (2014) 1096-1108.

[16] Khatami R., Levendis, Y.A. and Delichatsios, M., Combustion and Flame 162 (2015) 2508-2517.

[17] Carpender, A.M., Skorupka, N.M. "Coal Combustion Analysis and Testing" IEACR/64, IEA, Coal Research, London, 1993.

[18] Ballester, J., Jimenez, S., Combustion and Flame 142 (2005) 210-222.

[19] Li, H., Elliott, L, Rogers, H., Wall, T., Energy Fuels 28 (2014) 363-368. 
805

806

807

808

809

810

811

812

813

814

815

816

817

818

819

820

821

822

823

824

825

826

827

828

829

830

831

832

833

834

835

836

837

838

839

840

841

842

843

844

845

846

847

848

849

850

851

[20] Howard, J.B. and Essenhigh, R.H., Combustion and Flame 9 (1965) 337-339.

[21] Smith, I. W., Proceedings of the Combustion Institute 19 (1982) 1045-1065.

[22] Kobayashi, H., Howard J. B., Sarofim, A. F., Proceedings of the Combustion Institute 16 (1977) 411-425.

[23] Mitchell R. E., McLean W. J., Proceedings of the Combustion Institute 19 (1982) 1113-1122.

[24] Niksa, S., Mitchell, R.E., Hencken, K.R., Tichenor, D.A., Combustion \& Flame 60 (1984) 183-193.

[25] Joutsenoja, T., Saastamoinen, J., Aho, M., Hernberg, R., Energy \& Fuels 13 (1999) 130-145.

[26] Bragato, M., Joshi, K., Carlson, J.B., Tenorio, J.A.S., Levendis, Y.A. Fuel, 96 (2012) 43-50.

[27]_Bragato, M., Joshi, K., Carlson, J.B., Tenorio, J.A.S., Levendis, Y.A. Fuel, 96 (2012) 51-58.

[28] Mitchell, R. E., Combustion Science \& Technology 53 (1987) 165-186.

[29] Loewenberg, M., Levendis, Y.A., Combustion and Flame 84 (1991) 47-65.

[30] Hurt, R., Mitchell, R.E., Proceedings of the Combustion Institute 24 (1992) 1243-1250.

[31] Saito, M., Sadakata, M., Sato, M., Soutome, T., Murata, H. Combustion \& Flame 87 (1991) 1-12.

[32] Monson, C.R., Germane, G.J., Blackman, A.U., Smoot, L.D., Combustion \& Flame, 100 (1995), 669-683.

[33] Wall, T.F., Liu, G-S., Wu, H-W., Roberts, D.G., Benfell, K.E., Gupta, S., Lucas J.A., Harris, D.J. Progress Energy Combustion Science, 28 (2002) 405-433.

[34] Roberts, D.G., Harris, D.J., Wall, T.F., Energy and Fuels, 17 (2003) 887-895.

[35] Seeker, W.R., Samuelsen, G.S., Heap, M.P., Trolinger J.D., Proceedings of the Combustion Institute 18 (1981) 1213-1226

[36] McLean, W.J., Hardesty D.R., Pohl, J.H., Proceedings of the Combustion Institute 18 (1981) 1239-1247.

[37] Timothy, L. D., Sarofim, A. F., Froelich, D., Beer, J.M. Proceedings of the Combustion Institute 21 (1986) 1141.

[38] Timothy, L.D., Sarofim, A.F., Beer, J.M., Proceedings of the Combustion Institute 19 (1982) 1123-1130.

[39] Maffei, T., Khatami, R., Pierucci, S., Faravelli, T., Ranzi, E., Levendis Y. A., Combustion and Flame 160 (2013) 2559-2572.

[40] Murphy, J.J., Shaddix, C.R., Combustion \& Flame 144 (2006) 710-729.

[41] Shaddix, C.R. and Molina, A. Proc. Combust. Inst. 32 (2009) 2091-2098. 
852

[42] Hecht, E.S., Shaddix, C.R., Geier, M., Molina, A. and Haynes, B.S. Combustion \& Flame 159 (2012) 34373447.

[43] Zhang, L., Binner, E., Qiao, Y., Li, C-Z. Fuel 89 (2010), 2703-2712.

[44] Zhang, L., Binner, E., Chen, L., Qiao, Y., Li, C-Z. Bhattacharya, S., Ninomiya, Y., Energy and Fuels, 24 (2010), 4803-4811.

[45] Kim, Y-G., Kim, J-D., Lee B-H., Song, J-H., Chang Y-J., Jeon C-H., Energy and Fuels 24 (2010)6034-6040.

[46] Lee, H. and Choi, S., Combustion and Flame, 162 (2015) 2610-2620.

[47] Levendis Y.A., Khatami R. "Rank-Dependent Combustion Behavior of Pulverized Coals" Presented at the 39th Clearwater Clean Coal Conference, Clearwater Fl., June 1 - June 5, 2014.

[48] Suuberg, E. M., Peters, W. A., Howard, J. B., Proc. Combust. Inst. 17 (1979), 117-130.

[49] Solomon, P.R., Colket, M.B., Proc. Combust. Inst. 17 (1979), 131-143.

[50] Freihaut, J. D., Proscia, W. M., Seery, D.L. Energy and Fuels 3 (1989) 692-703.

[51] Thomas, G.R., Harris, I.R, Evans, D.G., Combustion \& Flame 12 (1968) 391-393.

[52] Leslie, I., Jost, M., Kruger, C. "Oxidation Reactivity of Pulverized Montana Rosebud Coal during Combustion." Presented at the spring Meeting of the Western States Section of the Combustion Institute, Los Angeles, 1982.

[53] Liu, H., Zailani, R., Gibbs, B.M., Fuel 84 (2005), 833-840.

[54] Howard, J.B. and Essenhigh, R.H., Proceedings of the Combustion Institute 11 (1967) 399-408.

[55] Annamalai, K., Durbetaki, P., Combustion and Flame 29 (1977) 193-208.

[56] Du, X., Annamalai, K., Combustion and Flame 97 (1994), 339-354.

[57] Riaza J., Khatami, R., Levendis, Y.A. Álvarez, L., Gil, M.V., Pevida, C. Rubiera, F., Pis, J.J., Biomass \& Bioenergy, 64 (2014), 162-174.

[58] Wall, T. F., Gupta, R. P., Gururajan, V. S. and Zhang, D., Fuel 70 (1991) 1011-1016.

[59] Zhang, D., Wall, T. F., Harris, D. J., Smith, I. W., Chen, J., and Stanmore, B. R., Fuel, 71 (1992) 1239-1246.

[60] Zhang, D., Wall, T. F., Fuel 73 (1994), 1114-1119.

[61] Essenhigh, R.H., Mirsa, M.K. and Shaw, D.W. Combustion and Flame, 77, (1989) 3-30.

[62] Gururajan, V.S., Gupta, R.P., Truelove, J.S., Combustion and Flame 81 (1990) 119-132.

[63] Huang, X., Jiang, X., Han, X., Wang, H., Energy and Fuels 22 (2008) 3756-3762. 
899

900

901

902

903

904

905

906

907

908

909

910

911

912

913

914

915

916

917

918

919

920

921

922

923

924

925

926

927

928

929

930

931

932

933

934

935

936

937

938

939

940

[64] Qiao Y., Zhang L., Binner E., Xu M., Li C., Fuel 89 (2010) 3381-3387.

[65] Lau, C.W., Niksa S., Combustion and Flame 90 (1992) 45-70.

[66] Lau, C.W., Niksa S., Combustion and Flame 95 (1993) 1-21.

[67] Molina, A. and Shaddix, C.R., Proc. Combust. Inst. 31 (2007), 1905-1912.

[68] Shaddix, C.R., Hecht, E.S., Jimenez, S. and Lee, S.M. "Evaluation of rank effects and gas temperature on coal char burning rates during oxy-fuel combustion." Presented at the $34^{\text {th }}$ International Technical Conference on Coal Utilization and Fuel Systems, Clearwater FI, May 31 - June 4, 2009.

[69] Levendis Y.A., Nam, S., Loewenberg, M., Flagan, R.C., Gavalas, G.R. Energy \& Fuels 3 (1989) 28-37.

[70] Field, M.A., Combustion and Flame 14 (1970) 237-248.

[71] Mitchell R.E., Akatenuk, J.A.E., Proc. Combust. Inst. 26 (1996), 3137-3144.

[72] Jimènez, S, Ballester, J. Combustion and Flame 151 (2007), 482-494.

[73] Baxter L.L., Combustion and Flame, 90 (1992), 174-184

[74] Kazanc F., Levendis, Y.A. Energy and Fuels, 26 (2012), 7127-7139.

[75] Helble, J. J., and Sarofim, A. F. Combustion and Flame, 76(1989), 183-196.

[76] Quann, R. J., and Sarofim, A. F. Proc. Combust. Inst. 19(1982), 1429-1440.

[77] Flagan, R. C., and Taylor, D. D. Aerosol Sci. Tech. 1 (1982), 371-383.

[78] Senior, C. L., and Flagan, R. C. Proc. Combust. Inst. 19 (1982), 1429-1440.

[79] Hernberg, R., Sternberg, J., Zethr/Eus, B. Combustion and Flame, 95(1993), 191 - 205.

[80] Sweeny, P.G., Grow, D.T. Energy Fuels, 3 (1989) 678-685.

[81] Boukara, R.; Gadiu, R.; Gilot, P.; Delfosse, L.; Prado, G. Proc. Combust. Inst. 24 (1996), 1127-1133.

[82] Jung H.; Kittelson, D.B.; Zahariah M.R. Environmental Science and Technology, 40 (2006), 4949-4955.

[83] Merchan-Merchan W.; Sanmiguel, S.G.; McCollam, S. Fuel, 102 (2012) 525-535.

[84] Merchan-Merchan W.; Correa Pugliese, J.F.; McCollam, S. Fuel, 156 (2015) 129-141.

[85] Lu, G.; Yan, Y. "Temperature Profiling of Pulverized Coal Flames Using Multicolor Pyrometric and Digital Imaging Techniques." IEEE Transactions on Instrumentation and Measurement, Vol 55(4) August 2006.

[86] Smart, J.; Lu, G.; Yan, Y.; Riley G. Combustion and Flame, 157 (2010) 1132-1139. 
941 [87] Schiemann, M.; Geier, M.; Shaddix, C.R.; Vorobiev, N.; Schrerer, V., M. Review of Scientific Instruments, 85 $942 \quad$ (2014) 075114.

943

[88] Chen, L., Yong, S-Z., Ghoniem, A.F. "Oxy-fuel combustion of pulverized coal: Characterization, fundamentals, 945 stabilization and CFD modeling." Progress in Energy and Combustion Science, 38 (2012) 156-214.

946

[89] Kimura N., Omata K., Kiga T., Takano, S., Shikisima, S. Energy Conver. Mgmt. 36 (1995) 805-808.

[90] Wall T, Liu Y, Spero C, Elliott L, Khare S, Rathnam R, et al. Chemical Engineering Research and Design 87( 2009), 1003-1016.

[91] Wang CS, Berry GF, Chang KC, Wolsky AM. Combustion and Flame 72(1988), 301-310.

[92] Kiga T., Takano, S., Kimura N., Omata K., Okawa, M., Mori, T., Kato, M. Energy Convers. Mgmt. 38 Suppl. (1997) S129-S134.

957 [93] Ochs, T., Oryshchyn, D., Gross, D., Patrick, B., Gross A., Dogan, C., Summers, C., Simmons, W., Schoenfield, 958 M. "Oxy-fuel Combustion Systems for Pollution Free Coal Fired Power Generation", Presented at the 29th Int'l. 959 Tech. Conf. on Coal Utilization \& Fuel Systems, Clearwater Florida, June 2004.

960

961

962

[94] Liu H, Zailani R, Gibbs BM. Fuel, (84) 2005, 2109-2115.

[95] Croiset E, Thambimuthu K, Palmer A. The Canadian Journal of Chemical Engineering (78) 2000, 402-407.

[96] Tan Y, Croiset E, Douglas MA, Thambimuthu KV. Fuel (85)2006, 507-512.

[97] Man CK, Gibbins JR, Cashdollar KL. Effect of coal type and oxyfuel combustion parameters on pulverised fuel ignition, In: 2007 ICCS\&T Conference Proceedings, Nottingham University, England, August 28-31; 2007. ISBN 929029-437-X.

[98] Man CK, Gibbins JR, Fuel (90) 2011, 294-304.

[99] Andersson K, Johansson R, Johnsson F, Leckner B. Energy \& Fuels (22) 2008, 1535-1541.

[100] Hjärtstam S, Andersson K, Johnsson F, Leckner B. Fuel (88) 2009, 2216-2224. 